\title{
28. MINERAL CHEMISTRY OF FOREARC VOLCANIC ROCKS FROM THE IZU-BONIN ARC, HOLES 792E AND 793B ${ }^{1}$
}

\author{
Henriette Lapierre,,${ }^{2,3}$ Rex N. Taylor, ${ }^{4}$ Olivier Rouer, ${ }^{3}$ and Hervé Chaisemartin ${ }^{3}$
}

\begin{abstract}
The Izu-Bonin forearc basement volcanic rocks recovered from Holes 792E and 793B show the same phenocrystic assemblage (i.e., plagioclase, two pyroxenes, and Fe-Ti oxides \pm olivine), but they differ in the crystallization sequence and their phenocryst chemistry. All the igneous rocks have suffered low-grade hydrothermal alteration caused by interaction with seawater. As a result, only clinopyroxenes, plagioclases, and oxides have preserved their primary igneous compositions.

The Neogene olivine-clinopyroxene diabasic intrusion (Unit II) recovered from Hole 793B differs from the basement basaltic andesites because it lacks $\mathrm{Cr}$-spinels and contains abundant titanomagnetites (Usp $\left.{ }_{38.5-46.4}\right)$ and uncommon $\mathrm{FeO}-$-rich $(\mathrm{FeO}=29 \%)$ spinels. It displays petrological and geochemical similarities to the Izu Arc volcanoes and, thus, can be considered as related to Izu-Bonin Arc magmatic activity.

The titanomagnetites (Usp $28.5-33$ ) in the calc-alkaline andesitic fragments of the Oligocene volcaniclastic breccia in Hole 793B (Unit VI) represent an early crystallization phase. The plagioclase phenocrysts enclosed in these rocks show oscillatory zoning and are less $\mathrm{Ca}$-rich $\left(\mathrm{An}_{78.6-67.8}\right)$ than the plagioclase phenocrysts of the diabase sill and the basement basaltic andesites. Their clinopyroxenes are Fe-rich augites $(\mathrm{Fs} \leq 19.4 ; \mathrm{FeO}=12 \%$ ) and thus, differ significantly from the clinopyroxenes of the Hole 793B arc-tholeiitic igneous rocks.

The 30-32 Ma porphyritic, two-pyroxene andesites recovered from Hole 792E are very similar to the andesitic clasts of the Neogene breccia recovered in Hole 793B (Unit VI). Both rocks have the same crystallization sequence, and similar chemistry of the $\mathrm{Fe}-\mathrm{Ti}$ oxides, clinopyroxenes, and plagioclases: that is, Ti-rich (Usp $25.5-30.4)$ magnetites, Fe-rich augites, and intensely oscillatory zoned plagioclases with bytownitic cores $\left(\mathrm{An}_{86-63}\right)$ and labradorite rims $\left(\mathrm{An}_{73-68}\right)$. They display a calc-alkaline differentiation trend (Taylor et al., this volume).

So, the basement highly porphyritic andesites recovered at Hole 792E, and the Hole 793B andesitic clasts of Unit VI show the same petrological and geochemical characteristics, which are that of calc-alkaline suites. These Oligocene volcanic rocks represent likely the remnants of the Izu-Bonin normal arc magmatic activity, before the forearc rifting and extension.

The crystallization sequence in the basaltic andesites recovered from Hole 793B is olivine-orthopyroxene-clinopyroxene-plagioclase-Fe-Ti oxides, indicating a tholeiitic differentiation trend for these volcanic rocks. Type $\mathrm{i}$ is an olivine-and $\mathrm{Cr}$-spinel bearing basaltic andesite whereas Type ii is a porphyritic pyroxene-rich basaltic andesite. The porphyritic plagioclase-rich basaltic andesite (Type iii) is similar, in most respects, to Type ii lavas but contains plagioclase phenocrysts. The last, and least common lava is an aphyric to sparsely phyric andesite (Type iv). Cr-spinels, included either in the olivine pseudomorphs of Type i lavas or in the groundmass of Type ii lavas, are $\mathrm{Cr}$-rich and $\mathrm{Mg}$-rich. In contrast, $\mathrm{Cr}$-spinels included in clinopyroxenes and orthopyroxenes (Types $\mathrm{i}$ and ii lavas) show lower $\mathrm{Cr}^{*}$ and $\mathrm{Mg}^{*}$ ratios and higher aluminium contents. Orthopyroxenes from all rock types are $\mathrm{Mg}$-rich enstatites. Clinopyroxenes display endiopsidic to augitic compositions and are $\mathrm{TiO}_{2}$ and $\mathrm{Al}_{2} \mathrm{O}_{3}$ depleted. All the crystals exhibit strong zoning patterns, usually normal, although, reverse zoning patterns are not uncommon. The plagioclases show compositions within the range of $\mathrm{An}_{90-64}$. The $\mathrm{Fe}-\mathrm{Ti}$ oxides of the groundmass are $\mathrm{TiO}_{2}$-poor $\left(\mathrm{Usp}_{16-17}\right)$.

The Hole 793B basaltic andesites show, like the Site 458 bronzites from the Mariana forearc, intermediate features between arc tholeiites and boninites: (1) $\mathrm{Cr}$-spinel in olivine, (2) presence of $\mathrm{Mg}$-rich bronzite, $\mathrm{Ca}-\mathrm{Mg}$-rich clinopyroxenes, and Ca-plagioclase phenocrysts, and (3) transitional trace element depletion and $\varepsilon_{\mathrm{Nd}}$ ratios between arc tholeiites and boninites. Thus, the forearc magmatism of the Izu-Bonin and Mariana arcs, linked to rifting and extension, is represented by a depleted tholeiitic suite that displays boninitic affinities.
\end{abstract}

\section{INTRODUCTION}

One of the major goals of Ocean Drilling Program Leg 126 was to examine the nature and composition of the Izu-Bonin forearc basement (Leg 126 Shipboard Scientific Party, 1989a, 1989b; Taylor, Fujioka, et al., 1990). Drilling reached basement at Sites 792 and 793, located, respectively, on a basement high upslope from a fork in Aoha Shima Canyon and in the center of the basin. Sedimentary rocks overlying the basement have biostratigraphic ages of about $31 \mathrm{Ma}$, indicating that the forearc basin was not formed earlier than the mid-Oligocene. The volcanic rocks recovered from the Izu-Bonin forearc region are mostly two-pyroxene andesites. The understanding

\footnotetext{
'Taylor, B., Fujioka, K., et al., 1992. Proc. ODP, Sci. Results, 126: College Station, TX (Ocean Drilling Program).

${ }^{2}$ URA-CNRS 69, Université Joseph Fourier, Institut Dolomieu, 15 Rue Maurice Gignoux, 38031 Grenoble Cedex, France.

${ }^{3}$ URA-CNRS 1366, Université d'Orléans, Laboratoire de Géologie Structurale, B. P. 6759, F. 45067, Orléans Cedex 2, France.

${ }^{4}$ Department of Geology. University of Southampton, Hampshire, SO9 5NH United Kingdom.
}

of the nature and origin of these andesites may add constraints to the tectono-magmatic evolution of intraoceanic island arcs and to the role of the upper mantle in arc-magma genesis.

This paper presents mineralogical (microprobe) and petrographic data from the recovered forearc basin lavas, compares them with other forearc volcanic rocks and island-arc tholeiites, and discusses their geodynamic implications. Because the characteristics of volcanic rocks differ between the two forearc sites, they are discussed separately. General descriptions of lithologies are summarized from the initial report (Taylor, Fujioka, et al., 1990). Lithologic unit numbers used in the text are those of the initial report.

\section{METHODS}

Minerals from 50 samples of the Izu-Bonin forearc basement recovered in Holes 793B and 792E were analyzed for major and minor elements. All elements were analyzed on a CAMEBAX microbeam electron microprobe at the Bureau de Recherches Géologiques et Minières (BRGM) and Université d'Orléans using the matrix corrections of Hénoc and Tong (1978). Analytical conditions 
are $15 \mathrm{kV}$ and $10 \mathrm{nA}$. Counting times range from 6-10 s (major elements) to $30 \mathrm{~s}$ ( $\mathrm{Cr}$ in clinopyroxenes). Under these conditions, concentrations $<0.1 \mathrm{wt} \%$ are considered unreliable. Mineral standards were obtained from the BRGM: albite for $\mathrm{Na}$, orthoclase for $\mathrm{K}$ and $\mathrm{Si}$, corundum for $\mathrm{Al}$, hematite for $\mathrm{Fe}$, forsterite for $\mathrm{Mg}$, apatite or wollastonite for $\mathrm{Ca}$, chromium for $\mathrm{Cr}$, rutile for $\mathrm{Ti}$, and rhodonite for $\mathrm{Mn}$.

\section{HOLE 793}

\section{Petrography}

The igneous rocks recovered from this hole consist of a Neogene olivine-clinopyroxene diabasic intrusion (Unit II), an Oligocene breccia containing clasts of andesite (Unit VI), and the basaltic andesite basement. Based on shipboard observations, this basement has been subdivided into 17 units of pillowed and massive flows interlayered with pillow-breccias and hyaloclastites (Taylor et al., this volume).

\section{Middle Neogene Olivine-Clinopyroxene Diabase Intrusion (Unit II)}

This diabase intrusion is characterized by phenocrysts of clinopyroxene, orthopyroxene, plagioclase, and olivine pseudomorphs set in an intersertal groundmass. Empty vesicles, outlined by smectite, are found throughout the intrusion. Olivine ( $3 \%$ modal) is completely replaced by saponite. Clinopyroxene (endiopside and augite) phenocrysts $(17 \%)$ are commonly associated with plagioclase $(40 \%)$ $\left(\mathrm{An}_{92-60}\right)$ in glomeroporphyritic aggregates. The groundmass is composed of abundant late-crystallized titanomagnetite (5\%), small plagioclase and clinopyroxene crystals, and an interstitial glass that has been altered to saponite.

The intrusion displays the crystallization sequence: olivine followed by orthopyroxene, followed by clinopyroxene, followed by plagioclase, followed by Fe-Ti oxides, indicating a tholeiitic differentiation trend.

The basal $0.5 \mathrm{~m}$ of the intrusion differs from its middle and upper parts in having more abundant glomeroporphyritic aggregates, larger phenocrysts, and orthopyroxene (bronzite) mantled by clinopyroxene. This zone represents an accumulation of phenocrysts directly above the lower chilled margin.

\section{Late Oligocene Volcaniclastic Breccia (Sedimentary Unit VI)}

This volcaniclastic breccia consists of up to $40 \%$ sand-size matrix with clasts dominated by vitrophyric andesite. The andesites contain $30 \%-40 \%$ modal plagioclase phenocrysts $(2-4 \mathrm{~mm})$, which show an oscillatory zoning $\left(\mathrm{An}_{78.6-67.8}\right)$ and abundant glassy inclusions. Augitic clinopyroxene $(10 \%)$ encloses early crystallized magnetite. With respect to the basement andesites, these andesitic clasts show significantly different mineralogical characteristics, all of them compatible with a calc-alkaline affinity: magnetite included in plagioclase and clinopyroxene phenocrysts, Fe-rich augite. In most respects, they are very similar to the andesites recovered at Site 792 (see below).

In the freshest andesite fragments, only the glassy groundmass is altered to saponite. However, most of the fragments are completely altered, with plagioclase and clinopyroxene phenocrysts replaced by smectites and calcite. Vesicles in these lavas are large $(5-20 \mathrm{~mm})$ and spherical or amoeboid in shape. They are rimmed by smectite and filled by zeolites.

\section{Igneous Basement}

Unit 1 of the Hole 793B basement is a heterolithic breccia containing ca. $60 \%$ clasts, $1-10 \mathrm{~cm}$ in size, set in a hyaloclastite matrix. The basaltic andesitic clasts, interpreted as pillow fragments, are pyroxene-phyric, plagioclase-phyric, or sparsely phyric lavas. Their mineralogical characteristics are very similar with those of the basement lava flows with the exception of the clinopyroxene phenocrysts chemistry (see below).
The andesitic basement has been dated as 25-30 Ma (Taylor and Mitchell, this volume). Four rock types were distinguished in the lava flows, below the breccia, on the basis of shipboard observations. Type $\mathrm{i}$ is an olivine- and Cr-spinel-bearing basaltic andesite found in Units 7 and 13. Plagioclase is present only as laths and microlites in a vesicular $(<5 \%)$ groundmass, which also includes both orthopyroxene and clinopyroxene as microphenocrysts. The margins and cracks of the olivine phenocrysts are outlined and filled by Fe-hydroxides/oxides and saponite, whereas the cores are replaced by celadonite-type smectites. In some cases, the olivine pseudomorphs are surrounded by clinopyroxenes, suggesting that olivine was not in equilibrium with the glass. Some of the $\mathrm{Cr}$-spinels are partially altered to hematite. Clinopyroxene (augite-endiopside) phenocrysts contain glassy inclusions, now pseudomorphed by smectites. Bronzite phenocrysts (occasionally rimmed by clinopyroxene) have small fractures filled with smectites. This basaltic andesite, which contains Cr-spinel-bearing olivine, clinopyroxene, and orthopyroxene phenocrysts, displays some similarities with boninites (Cameron et al., 1979, 1983; Wood, 1980; Tatsumi and Ishizoka, 1982): in particular, the presence of $\mathrm{Cr}$-spinel-bearing olivine, the lack of plagioclase phenocrysts, and orthopyroxene mantled by $\mathrm{Ca}$-rich pyroxene.

Porphyritic, pyroxene-rich, basaltic andesites (Type ii) are the most common rock type in the basement. The clinopyroxene phenocrysts, up to $1-10 \mathrm{~mm}$ across, are generally fresh but their margins are often altered to smectites (saponite). Fractures within these crystals are also filled by smectites. The bronzite phenocrysts (up to 20\%) are generally smaller and, like those in Type i lavas, are rimmed by calcic pyroxene. These orthopyroxenes are sometimes partially or wholly replaced by celadonite and smectites. Plagioclase is limited to flow-aligned microlites and laths in the glassy groundmass. The vesicles $(<3 \%)$ are commonly outlined by smectites or mixed-layer illite-smectites and, in the most altered samples, are filled with cristobalite, chalcedony or quartz.

The porphyritic, plagioclase-rich, basaltic andesites (Type iii) are found in Units 10 and 12 . These lavas are similar in most respects to Type ii lavas, but they contain $5 \%-10 \%$ plagioclase phenocrysts. Plagioclase (bytownite), clinopyroxene (endiopside-augite), and bronzite cluster in glomeroporphyritic aggregates. The felty groundmass is intersertal or trachytic. When this lava is found as pillow fragments, the vesicles are large (up to $1.5 \mathrm{~cm}$ in length), widespread, outlined by smectites, and filled with lamellate zeolites (heulandite).

The last, and least common lava is an aphyric to sparsely phyric andesite (Type iv) that is present in Units 6,9, and 16. These lavas are characterized by an intersertal trachytic groundmass very rich in plagioclase microlites $(\approx 4 \%)$ with rare, small plagioclase and endiopside $(2 \%)$ phenocrysts. This groundmass includes open, aligned fractures filled with smectites. The fractures connect tiny vesicles $(<1$ $\mathrm{mm}$ ) outlined by smectites and/or celadonite. When these lavas occur as fragments in hyaloclastites, their glassy groundmass is altered in fibrous zeolites.

\section{Igneous Mineralogy}

\section{Plagioclases}

Plagioclase is largely unaltered in rocks from this site and shows a distinct difference in habit related to the type of occurrence (e.g., massive flow, pillowed flow, or intrusion) and the magmatic affinity of the host lava. It occurs either as phenocrysts, laths, or quenched microlites. Plagioclase compositions determined by microprobe are listed in Table 1.

In the Or-Ab-An diagram (Deer et al., 1964, 1980; Fig. 1A), plagioclase laths in the diabase sill (Unit II) plot in the bytownitelabradorite fields $\left(\mathrm{An}_{82-60}\right)$ and their composition is the most $\mathrm{Ca}$-rich of all samples analyzed from the Izu-Bonin forearc drillings. In spite of the lack of visible oscillatory zoning, random cryptic variations in $\mathrm{Ca}$ content were found between the core and rim of individual grains. Plagioclase compositions also differ within the intrusion. At the base, 

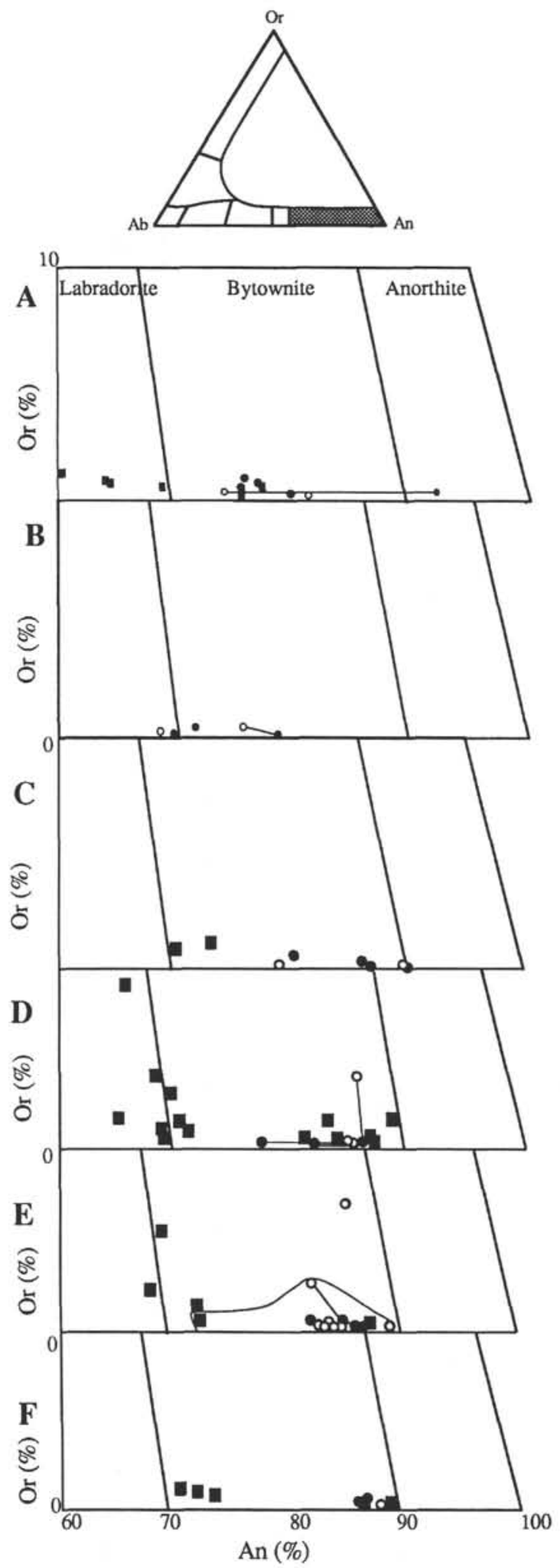

Figure 1. Plagioclase composition in the orthoclase (Or)-albite (Ab)-anorthite (An) diagram (after Deer et al., 1964, 1980), Hole 793B. A. Diabase sill. B. Andesitic clasts of the volcaniclastic breccia (Unit VI). C. Chromite-olivine basaltic andesite (Type i). D. Porphyritic pyroxene-rich basaltic andesite (Type ii). E. Porphyritic plagioclase-rich basaltic andesite (Type iii). F. Aphyric to sparsely basaltic andesite (Type iv). Filled squares $=$ microlites, filled circles $=$ phenocryst cores, and open circles $=$ phenocryst rims. they are more $\mathrm{Ca}$-rich, compared with the middle and upper parts where compositions are restricted to labradorite.

The plagioclases of the andesitic fragments in the volcaniclastic breccia (Unit VI) are more Na-rich $\left(\mathrm{An}_{79-69} ; \mathrm{Fig} .1 \mathrm{~B}\right)$ than those in the diabase. In these crystals, oscillatory zoning is ubiquitous.

The plagioclase compositions $\left(\mathrm{An}_{90-64} ; \mathrm{Figs} .1 \mathrm{C}-1 \mathrm{E}\right)$ of the basement basaltic andesites range from anorthite to labradorite. No chemical differences were observed between the four lava types defined above. The only chemical differences recognized are between phenocrysts and microlites in the Types ii and iii lavas, where the microlites are enriched in Na (Figs. 1C-1E).

\section{Clinopyroxene Compositions}

Clinopyroxenes occur as either phenocrysts, microphenocrysts, or quenched microlites. Compositions, determined by microprobe, are listed in Table 2. Their chemistry reflects the geochemical differences and magmatic affinities of the rocks in which they are included (Kushiro, 1960; Le Bas, 1962; Coombs, 1963; Nisbet and Pearce, 1977; Leterrier et al., 1982; Mollard et al., 1983).

In the Ca-Mg- $\left(\mathrm{Fe}^{\mathrm{T}}+\mathrm{Mn}\right)$ diagram (Poldervaart and Hess, 1951), the diabase sill (Unit II) clinopyroxenes display endiopsidic and augitic compositions (Fig. $2 \mathrm{~A}$ ), and are $\mathrm{Ca}$-rich $\left(\mathrm{Wo}_{31-43}\right)$ and $\mathrm{Na}-$ poor $\left(\mathrm{Na}_{2} \mathrm{O}<0.3 \%\right)$. The most Fe-rich augites $\left(\mathrm{Fs}_{13-17}\right)$ have the highest $\mathrm{TiO}_{2}\left(0.20 \%<\mathrm{TiO}_{2}<0.40 \%\right)$ and lowest $\mathrm{Cr}\left(0.15 \%<\mathrm{Cr}_{2} \mathrm{O}_{3}\right.$ $<0.40 \%$ ) contents. Some phenocrysts show chemical differences between core and rim, with either (1) a normal evolution marked by an iron enrichment and a magnesium depletion from core to rim with an endiopside core and an augite rim, or (2) a reversed evolution with an iron depletion from core to rim (Fig. 2A). These chemical differences within single phenocrysts are not associated with significant changes in the Ca contents.

In the basement, there are no chemical differences between clinopyroxene phenocrysts or microphenocrysts, regardless of whether they are included in massive or pillowed lavas or in breccia fragments. The clinopyroxenes of the andesitic clasts in the volcaniclastic breccia (Unit VI) are mainly $\mathrm{SiO}_{2}$-rich $\left(\mathrm{SiO}_{2}=52 \%\right)$, Fe-rich (Fs $\leq 19.4 ; \mathrm{FeO}$ $=12 \%$; Table 2 and Fig. $2 \mathrm{~B})$, Ti-poor $\left(\mathrm{TiO}_{2}=0.35 \%\right), \mathrm{Al}_{2} \mathrm{O}_{3}$-poor (1.82\%), and $\mathrm{Cr}$-poor $\left(\mathrm{Cr}_{2} \mathrm{O}_{3}=0.10 \%\right.$ ) augites (Fig. 2B). They show a reversed zoning from core to rim, marked by an $\mathrm{Mg}$ enrichment and a $\mathrm{Ca}$ and $\mathrm{Fe}$ depletion. Their chemical compositions, as well as the presence of titanomagnetite inclusions, are features of calc-alkaline volcanic rocks.

The clinopyroxene composition of the basement andesites is very homogeneous and does not exhibit significant differences between the lava types defined on the ship, with the exception of the clinopyroxenes of the uppermost breccia (Unit 1), which show higher total Fe contents ( $\mathrm{FeO}=7 \%-8 \%$; Table 2, Sample no. 20). All the clinopyroxenes cluster in the endiopside and augite fields; most of them plot along the join dividing the two fields (Figs. 2C-2F). They are $\mathrm{SiO}_{2}$-rich $\left(53 \%<\mathrm{SiO}_{2}\right.$ $<54 \%)$ and $\mathrm{MgO}$-rich $(\mathrm{MgO} \leq 18 \%)$, and very depleted in $\mathrm{TiO}_{2}(<0.15 \%)$ and $\mathrm{Na}_{2} \mathrm{O}\left(0.10 \%<\mathrm{Na}_{2} \mathrm{O}<0.2 \%\right)$. Their chemistry is very similar to the boninite clinopyroxenes of the Mariana Arc (Meijer et al., 1982; Natland, 1982) or the Bonin Islands (Kuroda et al., 1978); however, their $\mathrm{Cr}$ content $\left(0.3 \%<\mathrm{Cr}_{2} \mathrm{O}_{3}<0.55 \%\right)$ is slightly higher, and they are less aluminous $\left(\mathrm{Al}_{2} \mathrm{O}_{3} \leq 1.9 \%\right.$; Table 3$)$. This low alumina content suggests rather low-pressure crystallizing conditions (Deer et al., 1978; Herzberg, 1978; Gasparik, 1984).

The clinopyroxenes of the basement andesites, compared with those of arc-tholeiites and boninites, are more $\mathrm{Mg}$-rich $\left(\mathrm{En}_{49-51}\right.$; Fig. 3 and Table 3), suggesting that these basement andesites are the least evolved of this group (Kuroda et al., 1978; Meijer et al., 1982; Natland, 1982).

$\mathrm{A} \mathrm{Fe}, \mathrm{Al}$, and Ti enrichment (normal zoning) or depletion (reverse zoning) from core to rim was observed in all the analyzed pyroxenes (Figs. 2C-2F and Table 2). In some large phenocrysts in the chromiteolivine and plagioclase-rich andesite Types $\mathrm{i}$ and iii, the $\mathrm{Fe}$ and $\mathrm{Al}$ 
Table 1. Plagioclase representative compositions, Hole 793B.

\begin{tabular}{|c|c|c|c|c|c|c|c|c|c|c|c|}
\hline $\begin{array}{l}\text { Core, section } \\
\text { Interval }(\mathrm{cm})\end{array}$ & $\begin{array}{l}1 R-1(4) \\
132-136\end{array}$ & $\begin{array}{l}1 R-1(4) \\
132-136\end{array}$ & $\begin{array}{l}1 R-1(4) \\
132-136\end{array}$ & $\begin{array}{c}1 R-2(7) \\
61-65\end{array}$ & $\begin{array}{c}1 \mathrm{R}-2(7) \\
61-65\end{array}$ & $\begin{array}{c}85 R-2(18) \\
49-33\end{array}$ & $\begin{array}{c}85 \mathrm{R}-2(18) \\
49-33\end{array}$ & $\begin{array}{c}99 \mathrm{R}-1 \text { (48) } \\
140-144\end{array}$ & $\begin{array}{c}99 \mathrm{R}-1(48) \\
140-144\end{array}$ & $\begin{array}{c}99 \mathrm{R}-1(48) \\
140-144\end{array}$ & $\begin{array}{c}93 R-3(36) \\
96-100\end{array}$ \\
\hline $\begin{array}{l}\mathrm{SiO}_{2} \\
\mathrm{Al}_{2} \mathrm{O}_{3} \\
\mathrm{FeO} \\
\mathrm{CaO} \\
\mathrm{Na}_{2} \mathrm{O} \\
\mathrm{K}_{2} \mathrm{O}\end{array}$ & $\begin{array}{r}45.86 \\
35.00 \\
0.57 \\
18.03 \\
0.86 \\
0.04\end{array}$ & $\begin{array}{r}50.92 \\
31.34 \\
1.09 \\
14.36 \\
2.72 \\
0.04\end{array}$ & $\begin{array}{r}49.87 \\
31.50 \\
1.02 \\
15.15 \\
2.46 \\
0.06\end{array}$ & $\begin{array}{r}49.56 \\
31.52 \\
0.97 \\
14.91 \\
2.62 \\
0.01\end{array}$ & $\begin{array}{r}54.58 \\
27.94 \\
0.77 \\
11.61 \\
4.26 \\
0.13\end{array}$ & $\begin{array}{r}49.82 \\
31.86 \\
1.03 \\
15.23 \\
2.29 \\
0.01\end{array}$ & $\begin{array}{r}52.79 \\
30.01 \\
0.62 \\
12.92 \\
3.35 \\
0.06\end{array}$ & $\begin{array}{r}47.09 \\
33.59 \\
0.64 \\
17.32 \\
1.07 \\
-\end{array}$ & $\begin{array}{r}47.83 \\
33.32 \\
0.63 \\
17.23 \\
1.12 \\
0.03\end{array}$ & $\begin{array}{r}52.98 \\
29.01 \\
1.03 \\
13.16 \\
3.17 \\
0.12\end{array}$ & $\begin{array}{r}52.37 \\
28.81 \\
1.32 \\
13.01 \\
3.84 \\
0.17\end{array}$ \\
\hline Total & 100.36 & 100.47 & 100.06 & 99.59 & 99.29 & 100.24 & 99.75 & 99.71 & 100.16 & 99.47 & 99.52 \\
\hline$\%$ An & 91.8 & 74.3 & 77.0 & 75.8 & 59.6 & 78.6 & 67.8 & 89.9 & 89.3 & 69.1 & 64.5 \\
\hline State & $\begin{array}{l}\text { Fresh } \\
\text { phenocryst } \\
\text { core }\end{array}$ & $\begin{array}{l}\text { Fresh } \\
\text { phenocryst } \\
\text { rim }\end{array}$ & $\begin{array}{l}\text { Fresh } \\
\text { microlite }\end{array}$ & $\begin{array}{l}\text { Fresh } \\
\text { microlite }\end{array}$ & $\begin{array}{l}\text { Fresh } \\
\text { microlite }\end{array}$ & $\begin{array}{l}\text { Fresh } \\
\text { phenocryst } \\
\text { core }\end{array}$ & $\begin{array}{l}\text { Fresh } \\
\text { phenocryst } \\
\text { rim }\end{array}$ & $\begin{array}{l}\text { Fresh } \\
\text { phenocryst } \\
\text { rim }\end{array}$ & $\begin{array}{l}\text { Fresh } \\
\text { phenocryst } \\
\text { core }\end{array}$ & $\begin{array}{l}\text { Fresh } \\
\text { phenocryst } \\
\text { rim }\end{array}$ & $\begin{array}{l}\text { Fresh } \\
\text { microlite }\end{array}$ \\
\hline Rock type & Diabase & Diabase & Diabase & Diabase & Diabase & Unit VI & Unit VI & Type 1 & Type I & Type I & Type I \\
\hline
\end{tabular}

Notes: The structural formula was calculated on the basis of eight oxygenes. The numbers in parentheses correspond to the sample numbers analyzed for major and trace element chemistry (Taylor et al., this volume).
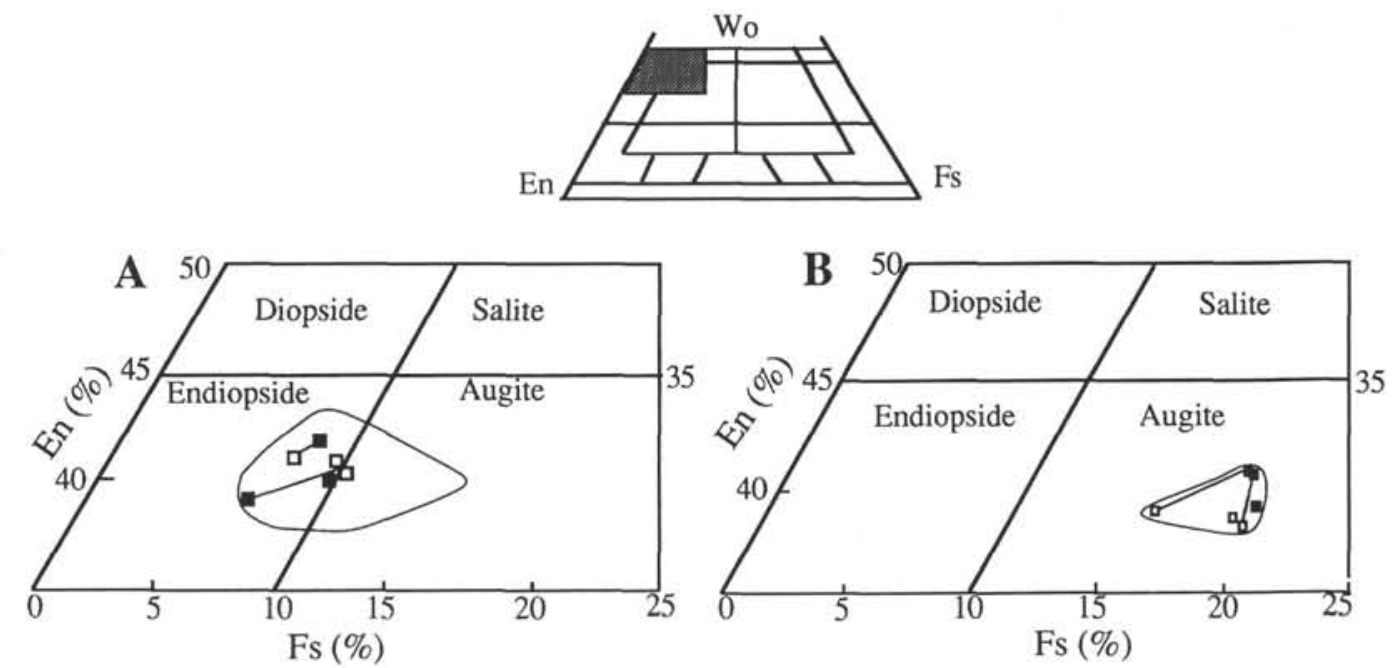

Figure 2. Clinopyroxene compositions in the wollastonite (Wo)-enstatite (En)-ferrosilite (Fs) diagram (after Poldervaart and Hess, 1951), Hole 793B. A. Diabase sill. B. Andesitic clasts of the volcaniclastic breccia (Unit VI). C. Chromite-olivine basaltic andesite (Type i). D. Porphyritic pyroxene-rich basaltic andesite (Type ii). E. Porphyritic plagioclase-rich basaltic andesite (Type iii). F. Aphyric to sparsely basaltic andesite (Type iv). Filled circles $=$ microphenocrysts and microlites, filled squares $=$ phenocryst cores, and open squares = phenocryst rims.

enrichment of their rims may be very important (Figs. 2C-2E). These chemical variations within single crystals are probably linked to the cooling rate. In particular, the rate of increase of the Ti and $\mathrm{Al}$ contents varies directly with the cooling rate (Gibbs, 1973; Walker et al., 1976; Groove and Bence, 1977).

\section{Clinopyroxene Composition as a Function of the Fractionation Process}

The clinopyroxene-bearing basement host lavas range from olivine-Cr spinel (Type i) to aphyric-sparsely basaltic (Type iv) andesites. The andesites of Type i (chromite-olivine) and Type ii (clinopyroxene-rich) represent the most mafic rocks, whereas the plagioclase-rich andesites (Type iii) and the sparsely aphyric basaltic andesites (Type iv) are the most evolved rocks of the forearc basin.

In Figure 4, Cr, $\mathrm{Al}, \mathrm{Ti}, \mathrm{Si}, \mathrm{Mg}, \mathrm{Ca}$, and $\mathrm{Na}$ elements of the clinopyroxene phenocrysts are plotted against $\mathrm{XFe}$ (i.e., $\mathrm{Fe} /[\mathrm{Fe} *+\mathrm{Mg}]$ ) ratio, considered as a differentiation index. Negative correlations exist with $\mathrm{Cr}$, $\mathrm{Mg}$, and $\mathrm{Si}$, whereas positive correlations exist with $\mathrm{Ti}$ and $\mathrm{Al}$, from olivine- $\mathrm{Cr}$ spinel (Type i) and clinopyroxene-rich (Type ii) basaltic andesite to plagioclase-rich basaltic andesite (Type iii). In contrast, $\mathrm{Ca}$ and $\mathrm{Na}$ remain roughly constant. In all the diagrams, the plots of the clinopyroxene phenocrysts of the aphyric to sparsely phyric andesite
(Type iv) and the diabase sill (Unit II) are randomly distributed along the differentiation trend. Finally, whatever diagram used, the plots of the clinopyroxene phenocrysts of the andesitic clasts of Unit VI form a distinct group, characterized by the highest XFe ratios.

Such chemical behavior in the clinopyroxenes of Hole 793B andesites show the following:

1. The clinopyroxenes of the andesitic clasts of Unit VI exhibit very different compositions and represent the most evolved minerals among all of the basement andesites:

2. The clinopyroxenes of the basement andesites display a regular evolution from Type i to Type iii basaltic andesites, compatible with crystal fractionation;

3. No significant chemical differences are present between the clinopyroxenes of the chromite-olivine (Type i) and the clinopyroxene-rich (Type ii) andesite lavas.

These results are in agreement with the whole-rock major chemistry presented by Taylor et al. (this volume). The clinopyroxene chemistry and the whole-rock compositions of their host rocks are a function of both phenocryst abundance and magma evolution. The differences in the petrology and chemistry of Types $\mathrm{i}$ and iii basaltic 
Table 1 (continued).

\begin{tabular}{|c|c|c|c|c|c|c|c|c|c|c|}
\hline $\begin{array}{c}92 \mathrm{R}-3(33) \\
55-59\end{array}$ & $\begin{array}{c}92 \mathrm{R}-3(33) \\
55-59\end{array}$ & $\begin{array}{c}92 \mathrm{R}-3(33) \\
55-59\end{array}$ & $\underset{55-59}{92 \mathrm{R}-3(33)}$ & $\begin{array}{c}96 \mathrm{R}-1 \text { ( } 42) \\
77-81\end{array}$ & $\begin{array}{c}86 \mathrm{R}-1(20) \\
128-131\end{array}$ & $\begin{array}{c}86 \mathrm{R}-1(20) \\
128-131\end{array}$ & $\begin{array}{c}88 R-1(26) \\
91-95\end{array}$ & $\begin{array}{c}86 \mathrm{R}-1 \text { ( }(26) \\
91-95\end{array}$ & $\begin{array}{c}86 \mathrm{R}-1(26) \\
91-95\end{array}$ & $\begin{array}{c}109 R-3(71) \\
50-55\end{array}$ \\
\hline $\begin{array}{r}48.77 \\
32.08 \\
0.44 \\
15.51 \\
2.43 \\
\end{array}$ & $\begin{array}{r}47.05 \\
33.60 \\
0.87 \\
17.12 \\
1.61 \\
0.05\end{array}$ & $\begin{array}{r}46.65 \\
33.32 \\
0.47 \\
17.34 \\
1.51 \\
-\end{array}$ & $\begin{array}{r}47.77 \\
33.00 \\
1.01 \\
16.14 \\
1.83 \\
0.18\end{array}$ & $\begin{array}{r}47.59 \\
33.15 \\
0.59 \\
16.87 \\
1.74 \\
0.04\end{array}$ & $\begin{array}{r}55.38 \\
26.85 \\
1.52 \\
12.19 \\
3.21 \\
0.24\end{array}$ & $\begin{array}{c}50.00 \\
30.8 \\
0.8 \\
15.22 \\
2.02 \\
0.11\end{array}$ & $\begin{array}{r}48.06 \\
32.94 \\
0.87 \\
16.41 \\
1.9 \\
-\end{array}$ & $\begin{array}{r}47.62 \\
32.86 \\
0.72 \\
16.20 \\
1.81 \\
0.08\end{array}$ & $\begin{array}{r}46.98 \\
33.48 \\
0.54 \\
16.77 \\
1.52 \\
0.03\end{array}$ & $\begin{array}{r}47.58 \\
33.35 \\
0.36 \\
17.13 \\
1.41 \\
0.01\end{array}$ \\
\hline 99.23 & 100.30 & 99.29 & 99.93 & 99.98 & 99.39 & 98.95 & 100.18 & 99.29 & 99.32 & 99.84 \\
\hline 77.9 & 85.2 & 86.4 & 82.1 & 84.1 & 66.7 & 80.1 & 82.7 & 82.8 & 85.8 & 87.0 \\
\hline $\begin{array}{l}\text { Fresh } \\
\text { microlite }\end{array}$ & $\begin{array}{l}\text { Fresh } \\
\text { phenocryst } \\
\text { core } \\
\text { Type II }\end{array}$ & $\begin{array}{l}\text { Fresh } \\
\text { phenocryst } \\
\text { rim } \\
\text { Type II }\end{array}$ & $\begin{array}{l}\text { Fresh } \\
\text { phenocryst } \\
\text { core } \\
\text { Type II }\end{array}$ & $\begin{array}{l}\text { Fresh } \\
\text { phenocryst } \\
\text { rim } \\
\text { Type II }\end{array}$ & $\begin{array}{l}\text { Fresh } \\
\text { microlite }\end{array}$ & $\begin{array}{l}\text { Fresh } \\
\text { phenocryst } \\
\text { core } \\
\text { Type III }\end{array}$ & $\begin{array}{l}\text { Fresh } \\
\text { phenocryst } \\
\text { core } \\
\text { Type III }\end{array}$ & $\begin{array}{l}\text { Fresh } \\
\text { phenocryst } \\
\text { intermediate } \\
\text { Type III }\end{array}$ & $\begin{array}{l}\text { Fresh } \\
\text { phenocryst } \\
\text { rim } \\
\text { Type III }\end{array}$ & $\begin{array}{l}\text { Fresh } \\
\text { phenocrys } \\
\text { t core } \\
\text { Type III }\end{array}$ \\
\hline
\end{tabular}
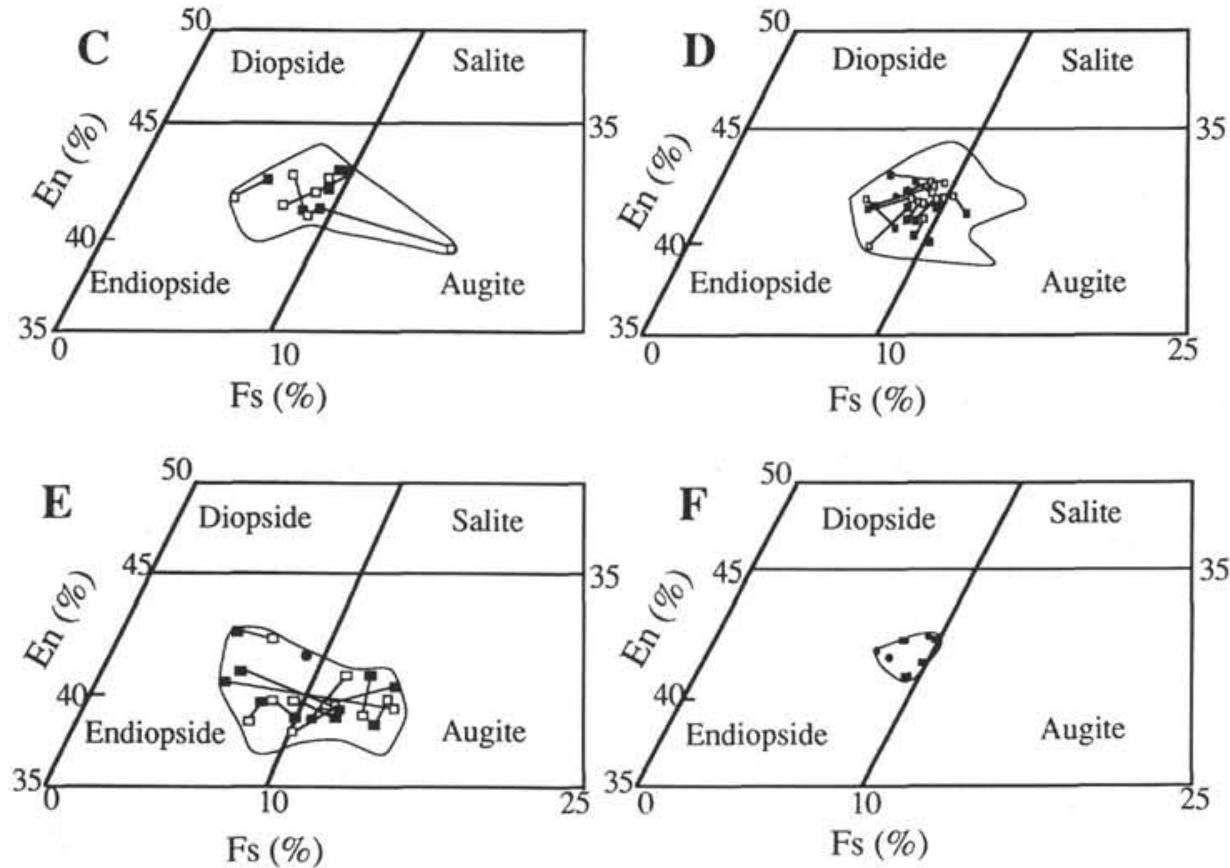

Figure 2 (continued).

andesites are likely related to crystal fractionation, whereas crystal accumulation is responsible for the genesis of the clinopyroxene-rich (Type ii) lavas.

\section{Orthopyroxenes}

Orthopyroxenes are found only in the diabase sill and in the basement andesites. They exhibit very homogeneous, Mg-rich, bronzite $(\mathrm{MgO} \approx 31 \%)$ compositions $\left(\mathrm{Fs}_{12.5-18} ; \mathrm{Wo} \approx_{3-4}\right.$; Table 4 and Fig. 5) very similar to orthopyroxenes from the Mariana Arc tholeiites (Bougault et al., 1982). However, small chemical variations are noticed within phenocrysts (Fig. 5).

\section{Chromium Spinels}

Chromium spinels (Table 5 and Fig. 6) occur as inclusions in the olivine pseudomorphs of the basement basaltic andesites (Type i). They are also found within the pyroxene phenocrysts of the clinopyroxene-rich basaltic andesites (Type ii). Contents of $\mathrm{Cr}^{*}[0.758<(\mathrm{Cr} / \mathrm{Cr}+\mathrm{Al})<$ $0.887]$ and $\mathrm{Mg}^{*}\left[0.407<\left(\mathrm{Mg} / \mathrm{Mg}+\mathrm{Fe}^{2+}\right)<0.531\right]$ are high (Table 5). The high $\mathrm{Cr}^{*}$ ratio $(>0.6)$ is a feature of island-arc tholeiites and is probably linked to a high oxygen fugacity (Kushiro, 1969).

The Cr-spinels included in the olivine pseudomorphs, or present in the groundmass of the Type ii andesites, are the most Cr-rich $(69.9 \%<$ $\left.\mathrm{Cr}_{2} \mathrm{O}_{3}<49 \%\right)$ and $\mathrm{Mg}$-rich $\left(0.508<\mathrm{Mg}^{*}<0.531\right)$ of all the analyzed spinels (Table 5) and cluster in the field of the $\mathrm{Cr}$-spinels of the Troodos boninitic basalts (Fig. 7; Cameron et al., 1979). However, the $\mathrm{Cr}$-spinels included in the clinopyroxenes of the same rock type (Types $\mathrm{i}$ and ii) show lower $\mathrm{Cr}^{*}$ and $\mathrm{Mg}$ * ratios and higher aluminium contents $\left(10.9 \%<\mathrm{Al}_{2} \mathrm{O}_{3}\right.$ $<8.9 \%$; Table 5). The most $\mathrm{Cr}$-depleted spinels $\left(\mathrm{Cr}_{2} \mathrm{O}_{3}=50.9 ; \mathrm{Cr}^{*}<\right.$ 0.758 ) are included in orthopyroxene phenocrysts of the Type ii lavas.

These differences in the chemistry of the $\mathrm{Cr}$-spinels suggest that the chromites included in the olivine phenocrysts or in the groundmass of Type $i$ andesite represent an equilibrium phase of the forearc tholeiites, whereas the $\mathrm{Cr}$-spinels that are richer in alumina and included in the pyroxenes reacted with the liquid (Fig. 7). 
Table 1 (continued).

\begin{tabular}{|c|c|c|c|c|c|c|c|}
\hline $\begin{array}{l}\text { Core, section } \\
\text { Interval }(\mathrm{cm})\end{array}$ & $\begin{array}{c}109 \mathrm{R}-3(71) \\
50-55\end{array}$ & $\begin{array}{c}100 \mathrm{R}-2(49) \\
50-55\end{array}$ & $\begin{array}{c}109 \mathrm{R}-3(71) \\
50-55\end{array}$ & $\begin{array}{c}100 \mathrm{R}-2(49) \\
16-19\end{array}$ & $\begin{array}{c}100 \mathrm{R}-2(49) \\
16-19\end{array}$ & $\begin{array}{c}100 \mathrm{R}-2(49) \\
16-19\end{array}$ & $\begin{array}{c}113 R-4(88) \\
35-41\end{array}$ \\
\hline $\begin{array}{l}\mathrm{SiO}_{2} \\
\mathrm{Al}_{2} \mathrm{O}_{3} \\
\mathrm{FeO} \\
\mathrm{CaO} \\
\mathrm{Na}_{2} \mathrm{O} \\
\mathrm{K}_{2} \mathrm{O}\end{array}$ & $\begin{array}{l}49.8 \\
31.58 \\
0.57 \\
15.65 \\
2.00 \\
0.04\end{array}$ & $\begin{array}{r}47.62 \\
33.57 \\
0.49 \\
17.24 \\
1.21 \\
0.03\end{array}$ & $\begin{array}{r}52.71 \\
29.33 \\
00.86 \\
13.55 \\
2.89 \\
0.12\end{array}$ & $\begin{array}{r}50.98 \\
0.47 \\
0.78 \\
14.57 \\
2.89 \\
0.08\end{array}$ & $\begin{array}{r}47.32 \\
33.18 \\
0.55 \\
17.18 \\
1.45 \\
0.07\end{array}$ & $\begin{array}{r}46.85 \\
33.53 \\
0.61 \\
17.45 \\
1.29 \\
-\end{array}$ & $\begin{array}{r}53.29 \\
28.86 \\
0.99 \\
12.92 \\
2.91 \\
0.37\end{array}$ \\
\hline Total & 99.64 & 100.16 & 99.43 & 99.77 & 100.25 & 99.73 & 99.34 \\
\hline$\%$ An & 81.0 & 88.6 & 71.6 & 73.2 & 86.1 & 88.2 & 69.4 \\
\hline Rock type & $\begin{array}{l}\text { Fresh } \\
\text { phenocryst } \\
\text { intermediate } \\
\text { Type III }\end{array}$ & $\begin{array}{l}\text { Fresh } \\
\text { phenocryst } \\
\text { rim } \\
\text { Type III }\end{array}$ & $\begin{array}{l}\text { Fresh } \\
\text { microlite }\end{array}$ & $\begin{array}{l}\text { Fresh } \\
\text { microlite }\end{array}$ & $\begin{array}{l}\text { Fresh } \\
\text { microphenocryst } \\
\text { core } \\
\text { Type IV }\end{array}$ & $\begin{array}{l}\text { Fresh } \\
\text { microphenocryst } \\
\text { rim } \\
\text { Type IV }\end{array}$ & $\begin{array}{l}\text { Fresh } \\
\text { microlite }\end{array}$ \\
\hline
\end{tabular}
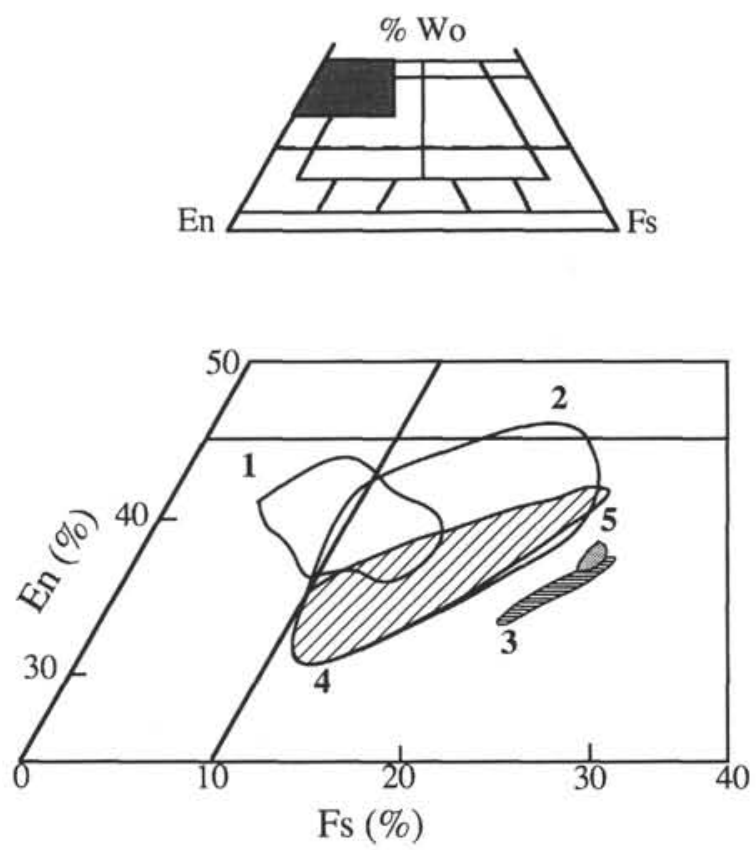

Figure 3. Comparison of the Izu-Bonin forearc andesitic basement clinopyroxenes with lavas from various settings. 1 = Izu-Bonin andesite-clinopyroxene field; 2 = Site 458 Marianas boninite-clinopyroxene field; $3=$ Bonin Islands clinopyroxene field; $4=$ Site 458 Marianas boninite-clinopyroxene field; 5 = Site 458 Marianas arc tholeiite-clinopyroxene field.

\section{Iron Spinels and Magnetites}

The diabase groundmass includes $\mathrm{FeO}$-rich spinels $(\mathrm{FeO}=29 \%$; $\mathrm{He}_{96}$; Table 6 and Fig. 6) and titanomagnetites $\left(13 \%<\mathrm{TiO}_{2}<15.5 \%\right.$; Usp $38.5-46.4$ ), close to the ulvospinel pole (Fig. 8 and Table 6; Buddington and Linsley, 1964). Magnetites in the groundmass of the basement basaltic andesites are less $\mathrm{TiO}_{2}$-rich $\left(\mathrm{TiO}_{2} \geq 3.56 \%\right.$; Usp ${ }_{16-17}$; Table 6) than those of the diabase sill.

Titanomagnetites included in Fe-rich augites of the andesitic fragments of the volcaniclastic breccia (Unit VI) differ from those of the basement andesites by having higher contents of $\mathrm{TiO}_{2}(4.3 \%$ $<\mathrm{TiO}_{2}<6.6 \%$; Usp $\left.28.5-33\right)$ and $\mathrm{MgO}(\leq 3 \%)$, and lower iron concentrations $(\mathrm{FeO} \leq 78 \%)$. These compositions are very similar with those of magnetites in calc-alkaline lavas (Gill, 1981).

\section{Secondary Mineralogy}

Hydrothermal activity has affected all the igneous rocks recovered from Hole 793B, leading to the occurrence of veins, cracks, and vesicles filled with quartz, zeolites, and smectites, and to the alteration of olivine and orthopyroxene. The secondary minerals are described below.

\section{Clay Minerals}

Olivine, glass, and, commonly, orthopyroxenes are replaced in all the igneous rocks (diabase sill, andesitic clasts of Unit VI, basement andesites) by clay minerals, whereas clinopyroxenes and plagioclases remain fresh. The chemistry of the clay minerals is listed in Table 7. Using the $\mathrm{Al}^{\mathrm{VI}}-\mathrm{Mg}-\mathrm{Fe}+\mathrm{Mn}$ diagram of Thorette (1987), three types of clay minerals can be distinguished (Fig. 9).

The first type of clay, which is also the most common, belongs to the saponite group. It is $\mathrm{Mg}$-rich, and its $\mathrm{K}_{2} \mathrm{O}$ content does not exceed $1.89 \%$. Its structural formula ranges between two poles: $\mathrm{Si}_{4.38} \mathrm{Al}_{0.94} \mathrm{Fe}_{0.85} \mathrm{Mg}_{4.22}$ $\mathrm{Mn}_{0.003} \mathrm{Na}_{0.14} \mathrm{~K}_{0.19} \mathrm{O}_{22}$ and $\mathrm{Si}_{7.03} \mathrm{Al}_{0.75} \mathrm{Fe}_{2.04} \mathrm{Mg}_{4.38} \mathrm{Mn}_{0.003} \mathrm{Na}_{0.005} \mathrm{~K}_{0.18}$ $\mathrm{O}_{22}$ (Deer et al., 1964, 1980). It replaces (1) the olivine phenocrysts of the diabase sill and the basement Type i basaltic andesite, and (2) the glass present in the groundmass or as inclusions in clinopyroxene and plagioclase phenocrysts of the basement lava Types $i$ and ii.

The second type of clay, which is depleted in $\mathrm{Al}^{\mathrm{VI}}$ and $\mathrm{Mg}$ and enriched in $\mathrm{Fe}+\mathrm{Mn}$ and $\mathrm{K}_{2} \mathrm{O}\left(2.84 \%<\mathrm{K}_{2} \mathrm{O}<10 \%\right)$, belongs to the glauconite-celadonite group. Its structural formula ranges between two poles: $\mathrm{Si}_{4.82} \mathrm{Al}_{0.6} \mathrm{Fe}_{1.56} \mathrm{Mg}_{2.09} \mathrm{Mn}_{0.02} \mathrm{Ca}_{0.13} \mathrm{Na}_{0.03} \mathrm{~K}_{0.91} \mathrm{O}_{22}$, and $\mathrm{Si}_{7.6} \mathrm{Al}_{0.77} \mathrm{Fe}_{2.8} \mathrm{Mg}_{2.09} \mathrm{Mn}_{0.03} \mathrm{Ca}_{0.27} \mathrm{Na}_{0} \mathrm{~K}_{0.56} \mathrm{O}_{22}$ (Deer et al., 1964, 1980). This group of minerals (1) occurs in the olivine pseudomorphs associated with saponite, (2) fills cracks in the orthopyroxene phenocrysts, or (3) coats vesicles in the sparsely phyric to aphyric andesites of the basement (lava Type iv). The distinction between celadonite (Al-poor) and glauconite (Al-rich) is not possible based solely on chemistry (Duplay and Buatier, 1990; Parron and Amauric, 1990) because of the presence of an isomorphic series between the $\mathrm{Al}$-rich and $\mathrm{Al}$-poor end members. $\mathrm{X}$-ray diffraction analysis is more suitable for distinguishing the two end members (Tazaki and Fyfe, this volume).

The third type of clay, which is poor in both $\mathrm{Mg}$ and $\mathrm{Fe}+\mathrm{Mn}$, stands out from the two other types by its richness in $\mathrm{Al}^{\mathrm{VI}}$ and $\mathrm{CaO}(\leq 5.80 \%)$. Its structural formula (from $\mathrm{Si}_{7.99} \mathrm{Al}_{2.18} \mathrm{Fe}_{0.62} \mathrm{Mg}_{1.53} \mathrm{Mn}_{0.03} \mathrm{Ca}_{0.38}$ $\mathrm{Na}_{0.11} \mathrm{~K}_{0.124}$ to $\mathrm{Si}_{7.01} \mathrm{Al}_{2.59} \mathrm{Fe}_{1.06} \mathrm{Mg}_{1.84} \mathrm{Mn}_{0.03} \mathrm{Ca}_{0.9} \mathrm{Na}_{0.4} \mathrm{~K}_{0.03} \mathrm{O}_{22}$ ) shows that it is illite (Deer et al., 1964). It generally replaces the groundmass glass of the basement andesites (Types ii, iii, and iv). It can also be found, associated with saponite, as a component of the altered glassy inclusions in the clinopyroxenes (Type iv lavas). 

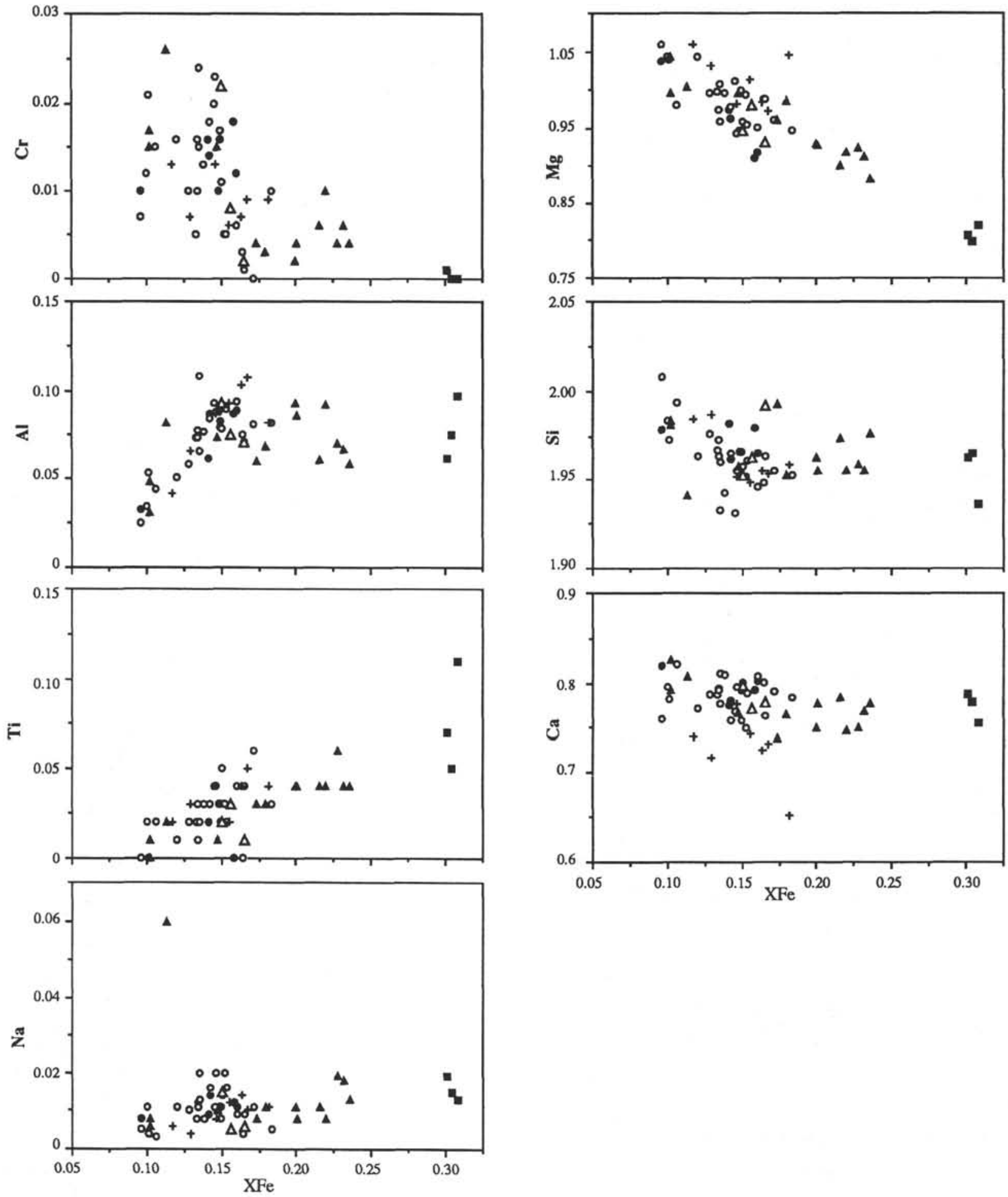

Figure 4. $\mathrm{Cr}, \mathrm{Al}, \mathrm{Ti}, \mathrm{Si}, \mathrm{Mg}, \mathrm{Ca}$, and $\mathrm{Na}$ vs. $\mathrm{XFe}(\mathrm{Fe} * / \mathrm{Fe} *+\mathrm{Mg})$ ratio diagram for the Hole 793B diabase, Unit $\mathrm{VI}$ and Hole $793 \mathrm{~B}$ basement clinopyroxenes. 
Table 2. Clinopyroxene representative compositions, Hole 793B.

\begin{tabular}{|c|c|c|c|c|c|c|c|c|c|}
\hline $\begin{array}{l}\text { Core, section } \\
\text { Interval }(\mathrm{cm})\end{array}$ & $\begin{array}{l}\text { IR-1 (4) } \\
132-136\end{array}$ & $\begin{array}{l}1 \mathrm{R}-1(4) \\
132-136\end{array}$ & $\begin{array}{c}1 R-2(7) \\
61-65\end{array}$ & $\begin{array}{c}1 R-2(7) \\
61-65\end{array}$ & $\begin{array}{c}\text { 1R-2 (7) } \\
61-65\end{array}$ & $\begin{array}{c}85 \mathrm{R}-2(18) \\
49-53\end{array}$ & $\begin{array}{c}85 \mathrm{R}-2 \text { (18) } \\
49-53\end{array}$ & $\begin{array}{c}86 \mathrm{R}-1(20) \\
128-131\end{array}$ & $\begin{array}{c}99 \mathrm{R}-1(48) \\
140-144\end{array}$ \\
\hline $\begin{array}{l}\mathrm{SiO}_{2} \\
\mathrm{Al}_{2} \mathrm{O}_{3} \\
\mathrm{TiO}_{2} \\
\mathrm{FeO} \\
\mathrm{MgO} \\
\mathrm{CaO} \\
\mathrm{MnO} \\
\mathrm{Cr}_{2} \mathrm{O}_{3} \\
\mathrm{Na}_{2} \mathrm{O}\end{array}$ & $\begin{array}{r}54.11 \\
2.41 \\
0.16 \\
6.33 \\
18.28 \\
18.72 \\
0.33 \\
0.23 \\
0.20\end{array}$ & $\begin{array}{r}53.68 \\
2.49 \\
0.14 \\
5.92 \\
17.88 \\
18.66 \\
0.12 \\
0.49 \\
0.16\end{array}$ & $\begin{array}{r}53.97 \\
1.80 \\
0.20 \\
10.07 \\
18.31 \\
15.01 \\
0.2 \\
0.08 \\
0.10\end{array}$ & $\begin{array}{r}54.53 \\
0.99 \\
0.07 \\
4.61 \\
19.50 \\
18.97 \\
0.06 \\
0.46 \\
0.08\end{array}$ & $\begin{array}{r}53.09 \\
2.85 \\
0.23 \\
7.06 \\
17.06 \\
18.88 \\
0.21 \\
0.26 \\
0.15\end{array}$ & $\begin{array}{r}52.54 \\
1.40 \\
0.26 \\
11.10 \\
14.48 \\
19.69 \\
0.50 \\
0.03 \\
0.26\end{array}$ & $\begin{array}{r}51.92 \\
2.23 \\
0.12 \\
9.60 \\
16.16 \\
18.84 \\
0.07 \\
0.18 \\
0.20\end{array}$ & $\begin{array}{r}52.87 \\
1.72 \\
0.11 \\
8.29 \\
15.96 \\
19.57 \\
0.14 \\
0.23 \\
0.16\end{array}$ & $\begin{array}{r}53.66 \\
2.04 \\
0.10 \\
5.39 \\
17.36 \\
20.22 \\
0.09 \\
0.35 \\
0.15\end{array}$ \\
\hline Total & 100.77 & 99.54 & 99.78 & 99.27 & 99.80 & 100.26 & 99.32 & 99.05 & 99.36 \\
\hline $\begin{array}{l}\text { \%En } \\
\% \mathrm{Fs} \\
\% \text { Wo }\end{array}$ & $\begin{array}{l}51.1 \\
10.5 \\
38.0\end{array}$ & $\begin{array}{r}51.6 \\
9.8 \\
38.6\end{array}$ & $\begin{array}{l}52.5 \\
16.6 \\
30.9\end{array}$ & $\begin{array}{r}54.5 \\
7.3 \\
38.2\end{array}$ & $\begin{array}{l}49.1 \\
11.8 \\
39.1\end{array}$ & $\begin{array}{l}41.2 \\
18.5 \\
40.3\end{array}$ & $\begin{array}{l}46.0 \\
15.4 \\
38.6\end{array}$ & $\begin{array}{l}45.9 \\
13.6 \\
40.5\end{array}$ & $\begin{array}{r}49.6 \\
8.8 \\
41.6\end{array}$ \\
\hline $\begin{array}{l}\mathrm{XFe} \\
\text { AllV } \\
\text { AlVl } \\
\text { Ti }+\mathrm{Cr} \\
\mathrm{Ca}+\mathrm{Na}\end{array}$ & $\begin{array}{l}0.163 \\
0.045 \\
0.058 \\
0.011 \\
0.739\end{array}$ & $\begin{array}{l}0.157 \\
0.041 \\
0.066 \\
0.018 \\
0.741\end{array}$ & $\begin{array}{l}0.236 \\
0.021 \\
0.057 \\
0.008 \\
0.597\end{array}$ & $\begin{array}{l}0.117 \\
0.015 \\
0.027 \\
0.015 \\
0.746\end{array}$ & $\begin{array}{l}0.188 \\
0.055 \\
0.068 \\
0.014 \\
0.752\end{array}$ & $\begin{array}{l}0.301 \\
0.037 \\
0.025 \\
0.008 \\
0.807\end{array}$ & $\begin{array}{l}0.250 \\
0.062 \\
0.036 \\
0.008 \\
0.768\end{array}$ & $\begin{array}{l}0.226 \\
0.032 \\
0.043 \\
0.010 \\
0.793\end{array}$ & $\begin{array}{l}0.148 \\
0.034 \\
0.054 \\
0.013 \\
0.805\end{array}$ \\
\hline Rock type & $\begin{array}{l}\text { Fresh } \\
\text { phenocryst } \\
\text { core } \\
\text { Diabase }\end{array}$ & $\begin{array}{l}\text { Fresh } \\
\text { phenocryst } \\
\text { rim } \\
\text { Diabase }\end{array}$ & $\begin{array}{l}\text { Fresh } \\
\text { microlite }\end{array}$ & $\begin{array}{l}\text { Fresh } \\
\text { phenocryst } \\
\text { core } \\
\text { Diabase }\end{array}$ & $\begin{array}{l}\text { Fresh } \\
\text { phenocryst } \\
\text { rim } \\
\text { Diabase }\end{array}$ & $\begin{array}{l}\text { Fresh } \\
\text { phenocryst } \\
\text { core } \\
\text { Unit VI }\end{array}$ & $\begin{array}{l}\text { Fresh } \\
\text { phenocryst } \\
\text { rim } \\
\text { Unit VI }\end{array}$ & $\begin{array}{l}\text { Fresh } \\
\text { phenocryst } \\
\text { core } \\
\text { Type I }\end{array}$ & $\begin{array}{l}\text { Fresh core } \\
\text { phenocryst } \\
\text { core } \\
\text { Type I }\end{array}$ \\
\hline
\end{tabular}

Notes: The structural formulas was calculated on the basis of six oxygenes. The numbers in parentheses correspond to the sample numbers analyzed for major and trace element chemistry (Taylor et al., this volume).

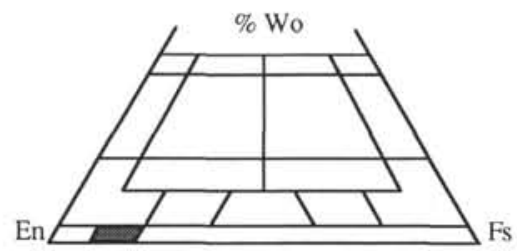

Wo $(\%)$
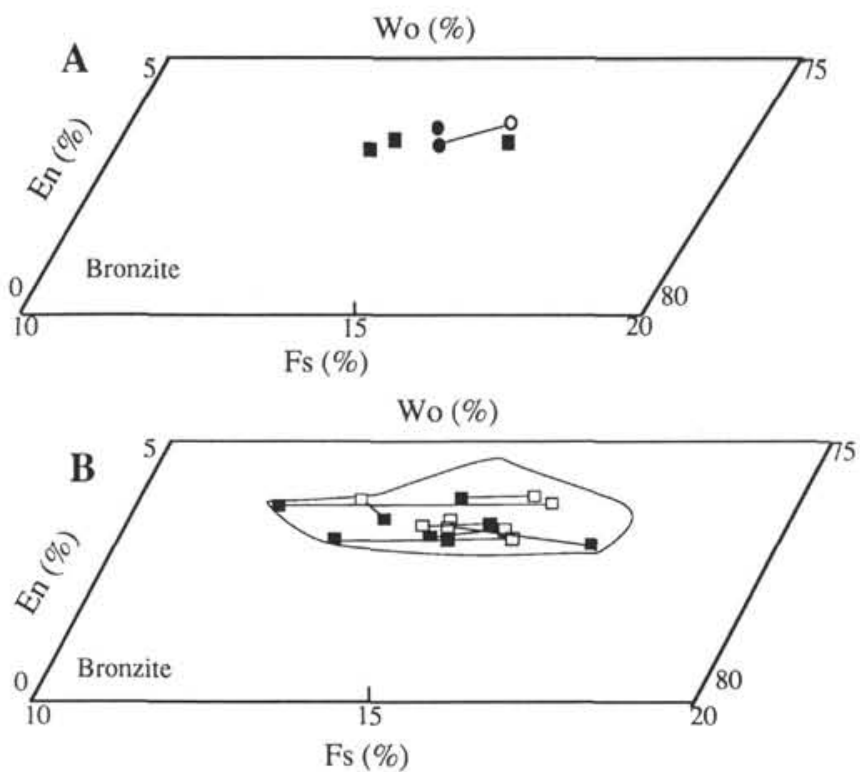

Figure 5. Orthopyroxene composition in the wollastonite (Wo)-enstatite (En)-ferrosilite $(\mathrm{Fs})$ diagram (after Poldervaart and Hess, 1951), Hole 793B. A. Circles = chromite-olivine basaltic andesite (Type i) with filled circles $=$ phenocryst core and open circles $=$ phenocryst rim; filled squares $=$ porphyritic pyroxene-rich basaltic andesite (Type ii); and open squares = porphyritic plagioclase-rich basaltic andesite (Type iii). B. Aphyric to sparsely basaltic andesite (Type iv) with filled squares $=$ phenocryst core and open squares $=$ phenocryst rim.

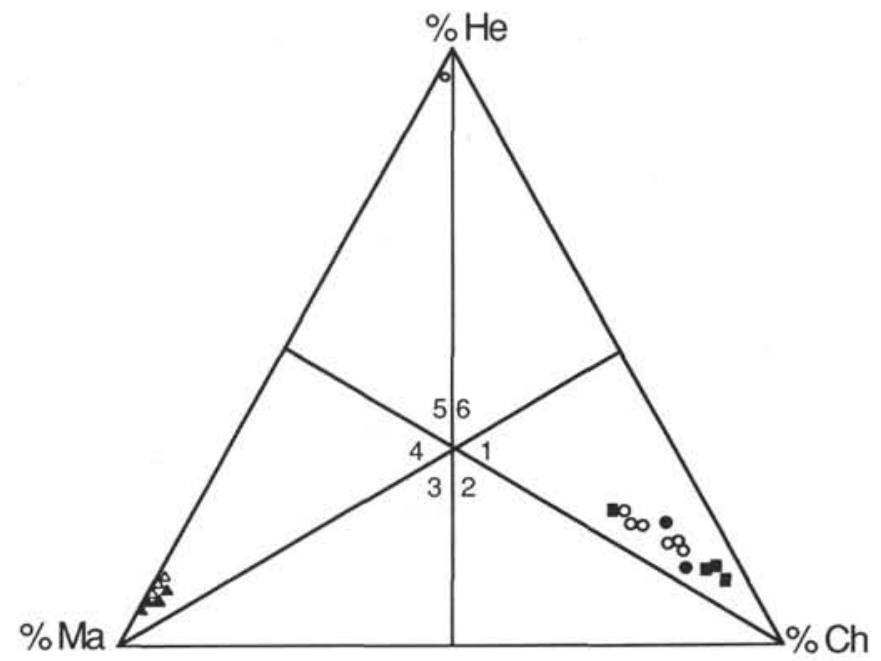

Figure 6. Oxide classifications in the magnetite (Ma)-chromite (Ch)-hercynite (He) diagram (after Stevens, 1944), Hole 793B. Filled triangles = diabase; open triangles $=$ andesitic clasts of the volcaniclastic breccia (Unit VI); open circles = chromite-olivine basaltic andesite (Type i); filled squares = porphyritic pyroxenerich basaltic andesite (Type ii); filled circles = porphyritic plagioclase-rich basaltic andesite (Type iii) and aphyric to sparsely basaltic andesite (Type iv).

\section{Zeolites}

Zeolites are only found as infills of fractures and vesicles (andesite Type iii). They do not occur as a product of glass alteration. They form large crystals up to $3 \mathrm{~mm}$ long. Their very homogeneous composition corresponds to heulandite with a low Si/Al ratio $(<4$; Boles, 1972, $1977)$ and low Ca content ( $\ 4.03 \%$; Table 8 ) (Deer et al., 1964, 1980). The structural formula ranges from $\mathrm{Si}_{28.88} \mathrm{Al}_{7.80} \mathrm{Fe}_{0} \mathrm{Mg}_{0.01} \mathrm{Na}_{2.66}$ $\mathrm{Ca}_{1.91} \mathrm{~K}_{0.16} \mathrm{O}_{72}$ to $\mathrm{Si}_{28.64} \mathrm{Al}_{7.52} \mathrm{Fe}_{0} \mathrm{Mg}_{0} \mathrm{Na}_{1.63} \mathrm{Ca}_{1.67} \mathrm{~K}_{0.14} \mathrm{O}_{72}$.

Heulandite is commonly associated with smectite and saponite in the low-grade hydrothermal alteration of basic to intermediate vol- 
Table 2 (continued).

\begin{tabular}{|c|c|c|c|c|c|c|c|c|c|}
\hline $\begin{array}{c}99 \mathrm{R}-1(48) \\
140-144\end{array}$ & $\begin{array}{c}110 \mathrm{R}-3(75) \\
78-83\end{array}$ & $\begin{array}{c}110 \mathrm{R}-3(75) \\
78-83\end{array}$ & $\begin{array}{c}110 \mathrm{R}-3(75) \\
78-83\end{array}$ & $\begin{array}{c}93 \mathrm{R}-1(36) \\
96-100\end{array}$ & $\begin{array}{c}92 \mathrm{R}-2(30) \\
70-74\end{array}$ & $\begin{array}{c}92 \mathrm{R}-2(30) \\
70-74\end{array}$ & $\begin{array}{c}92 \mathrm{R}-2(30) \\
70-74\end{array}$ & $\begin{array}{c}92 \mathrm{R}-2(31) \\
113-117\end{array}$ & $\begin{array}{c}92 \mathrm{R}-3(33) \\
55-59\end{array}$ \\
\hline $\begin{array}{r}54.36 \\
1.86 \\
0.09 \\
5.55 \\
16.93 \\
20.12 \\
0.17 \\
0.21 \\
0.04\end{array}$ & $\begin{array}{r}53.59 \\
2.02 \\
0.10 \\
5.22 \\
17.67 \\
19.92 \\
0.25 \\
0.47 \\
0.20\end{array}$ & $\begin{array}{r}53.59 \\
1.80 \\
0.08 \\
5.20 \\
18.42 \\
19.49 \\
0.05 \\
0.72 \\
0.10\end{array}$ & $\begin{array}{r}51.95 \\
3.98 \\
0.38 \\
9.76 \\
15.52 \\
17.89 \\
0.09 \\
0.38\end{array}$ & $\begin{array}{r}53.57 \\
2.10 \\
0.11 \\
5.23 \\
18.32 \\
20.66 \\
0.09 \\
0.20 \\
0.13\end{array}$ & $\begin{array}{r}54.12 \\
1.73 \\
0.07 \\
5.03 \\
18.42 \\
20.22 \\
0.07 \\
0.18 \\
0.11\end{array}$ & $\begin{array}{r}54.06 \\
1.52 \\
0.05 \\
4.92 \\
17.95 \\
20.36 \\
0.26 \\
0.69 \\
0.19\end{array}$ & $\begin{array}{r}53.68 \\
2.28 \\
0.09 \\
5.97 \\
17.31 \\
20.34 \\
0.35 \\
0.36 \\
0.35\end{array}$ & $\begin{array}{r}54.05 \\
1.38 \\
0.05 \\
4.83 \\
17.97 \\
19.88 \\
0.14 \\
0.71 \\
0.31\end{array}$ & $\begin{array}{r}53.31 \\
1.88 \\
0.22 \\
6.47 \\
17.60 \\
20.12 \\
\overline{-} \\
0.15\end{array}$ \\
\hline 99.33 & 99.44 & 99.45 & 99.95 & 100.41 & 99.95 & 100.00 & 100.63 & 99.08 & 99.75 \\
\hline $\begin{array}{r}48.9 \\
9.3 \\
41.8\end{array}$ & $\begin{array}{r}50.4 \\
8.8 \\
40.8\end{array}$ & $\begin{array}{r}52.1 \\
8.3 \\
39.6\end{array}$ & $\begin{array}{l}45.8 \\
16.3 \\
37.9\end{array}$ & $\begin{array}{r}50.7 \\
8.3 \\
41.0\end{array}$ & $\begin{array}{r}51.4 \\
8.0 \\
40.6\end{array}$ & $\begin{array}{r}50.6 \\
8.2 \\
41.2\end{array}$ & $\begin{array}{l}48.8 \\
10.0 \\
41.2\end{array}$ & $\begin{array}{r}49.3 \\
9.3 \\
41.4\end{array}$ & $\begin{array}{l}49.3 \\
10.2 \\
40.5\end{array}$ \\
\hline $\begin{array}{l}0.155 \\
0.011 \\
0.069 \\
0.008 \\
0.792\end{array}$ & $\begin{array}{l}0.142 \\
0.038 \\
0.049 \\
0.017 \\
0.795\end{array}$ & $\begin{array}{l}0.137 \\
0.041 \\
0.037 \\
0.023 \\
0.770\end{array}$ & $\begin{array}{l}0.261 \\
0.081 \\
0.092 \\
0.011 \\
0.735\end{array}$ & $\begin{array}{l}0.138 \\
0.055 \\
0.035 \\
0.009 \\
0.813\end{array}$ & $\begin{array}{l}0.133 \\
0.033 \\
0.041 \\
0.007 \\
0.795\end{array}$ & $\begin{array}{l}0.133 \\
0.032 \\
0.033 \\
0.021 \\
0.807\end{array}$ & $\begin{array}{l}0.162 \\
0.049 \\
0.049 \\
0.012 \\
0.810\end{array}$ & $\begin{array}{l}0.155 \\
0.044 \\
0.061 \\
0.025 \\
0.802\end{array}$ & $\begin{array}{l}0.192 \\
0.032 \\
0.052 \\
0.006 \\
0.789\end{array}$ \\
\hline $\begin{array}{l}\text { Fresh } \\
\text { phenocryst } \\
\text { rim } \\
\text { Type I }\end{array}$ & $\begin{array}{l}\text { Fresh } \\
\text { phenocryst } \\
\text { core } \\
\text { Type I }\end{array}$ & $\begin{array}{l}\text { Fresh } \\
\text { phenocryst } \\
\text { intermediate } \\
\text { Type I }\end{array}$ & $\begin{array}{l}\text { Fresh } \\
\text { phenocryst } \\
\text { rim } \\
\text { Type I }\end{array}$ & $\begin{array}{l}\text { Fresh } \\
\text { phenocryst } \\
\text { rim } \\
\text { Type I }\end{array}$ & $\begin{array}{l}\text { Fresh } \\
\text { phenocryst } \\
\text { core } \\
\text { Type II }\end{array}$ & $\begin{array}{l}\text { Fresh } \\
\text { phenocryst } \\
\text { intermediate } \\
\text { Type II }\end{array}$ & $\begin{array}{l}\text { Fresh } \\
\text { phenocryst } \\
\text { rim } \\
\text { Type II }\end{array}$ & $\begin{array}{l}\text { Fresh } \\
\text { microphenocryst } \\
\text { Type II }\end{array}$ & $\begin{array}{l}\text { Fresh } \\
\text { phenocryst } \\
\text { core } \\
\text { Type II }\end{array}$ \\
\hline
\end{tabular}

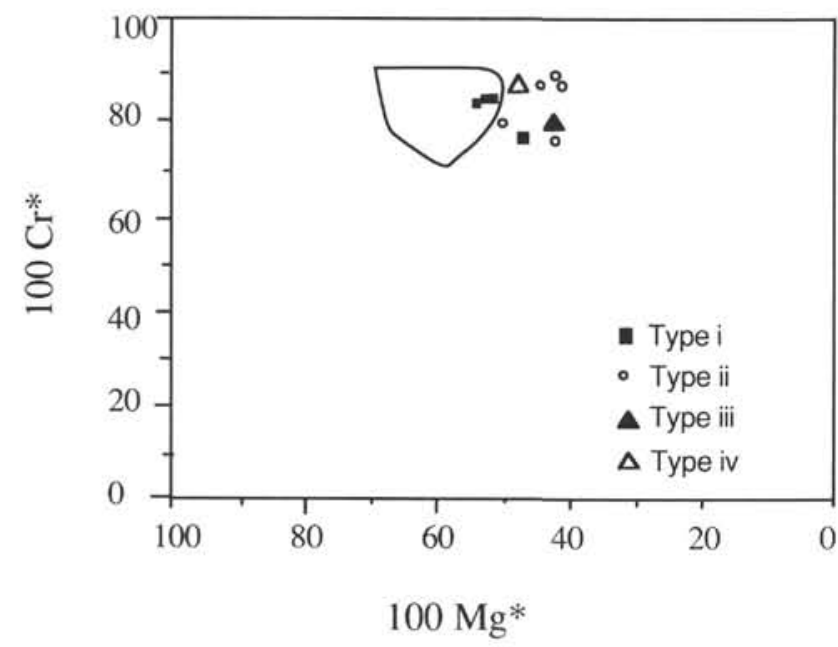

Figure 7. Chromite composition in the $100 \mathrm{C} / \mathrm{Cr}+\mathrm{Al}$ vs. $100 \mathrm{Mg} / \mathrm{Mg}+\mathrm{Fe}^{2+}$ diagram (after Dick and Bullen, 1984), Hole 793B. The polygon represents the boninite chromium-spinel field (after Cameron et al., 1979).

canic rocks (Boles, 1972). Heulandite precipitates at very low temperatures $\left(50^{\circ}-100^{\circ} \mathrm{C}\right)$ and is replaced by laumontite (Ca-rich zeolite) when the temperature exceeds $100^{\circ} \mathrm{C}$ (Winkler, 1974).

\section{HOLE 792}

\section{Petrography}

The igneous rocks recovered from the basement at this site consist of five units: three levels of andesitic flows interbedded with hyaloclastite beds, and two major hyaloclastitic-volcanic horizons. The dominant volcanic lithology recovered from this hole is a highly porphyritic, two-pyroxene andesite.

Unit 1 (Samples 126-792E-70R-1, Piece 1, through -74R-1, Piece 3 ) is a porphyritic andesitic flow that contains about $30 \%$ euhedral fresh plagioclase, $0.5-4 \mathrm{~mm}$ in diameter, with $\leq 12 \%$ total pyroxenes. There are two thin hyaloclastic layers in this unit. The plagioclases in the lavas show an intense oscillatory zoning (see next section) and abundant glassy inclusions. The clinopyroxenes are always fresh and form large (up to 7-8 mm) crystals with a marked zoning along their rims. The orthopyroxenes, always altered to smectites, occur as laths up to $10 \mathrm{~mm}$ long. The largest crystals are rimmed by small clinopyroxenes, but their cores remain fresh (Fe-rich bronzite). Titanomagnetite occurs as inclusions in the phenocrysts and groundmass. Skeletal pseudomorphs of olivine characterize the uppermost part of this unit, whereas quartz xenocrysts occur at the base. Rounded xenoliths are common in the andesites of this unit as well as in Units 3 and 5. The largest are $<10 \mathrm{~cm}$ in diameter. In Unit 1 , they consist of coarser grained variants of the andesite (orthopyroxene diabase and intersertal andesite; Samples 126-792E-73R-1, Pieces 18-21).

Unit 2 (Samples 126-792E-74R-1, Piece 4, through -74R-1, Piece 9) is an andesitic hyaloclastic breccia. It is similar to the hyaloclastite bands present in Unit 1, but it differs in that it contains hard andesitic clasts, $1-4 \mathrm{~cm}$ in diameter, sparsely distributed in a matrix of glass shards and xenocryst fragments. The andesitic clasts (Sample 126792E-74R-1, $108 \mathrm{~cm}$ ) are similar in composition to the Unit 1 andesite, but they occur as large clots, up to $3 \mathrm{~cm}$ in diameter, of orthopyroxene pseudomorphs mantled by small fresh clinopyroxene plagioclase with clinopyroxene inclusions and intensely zoned clinopyroxenes. Glomeroporphyritic aggregates of intensely zoned plagioclase and/or clinopyroxenes are also present.

Unit 3 (Samples 126-792E-74R-1, Piece 10, through -75R-2, Piece 9) consists of porphyritic andesite flows, similar to Unit 1 in phenocryst abundance and proportions. Quartz xenocrysts are present. The andesite displays fluidal textures. Orthopyroxenes are systematically replaced by smectites \pm quartz and are commonly surrounded by intensely oscillatory zoned plagioclase. The clinopyroxenes may include small plagioclase crystals. The titanomagnetite is systematically included in the phenocrysts.

Unit 4 (Samples 126-792E-76R-1, Piece 1, through -76R-1, Piece 3 ) is a volcanic breccia. It consists of rounded, pebble-size clasts of lava in an altered, green, hyaloclastite matrix. Three clasts were recovered: a celadonite-stained andesite, a porphyritic andesite similar to the adjacent lava, and a metabasaltic rock (Taylor, Fujioka, et al., 1990, p. 264).

Unit 5 (Samples 126-792E-76R-1, Piece 4, through -78R-2, Piece 2) consists of porphyritic andesite flows similar to those of Unit 3; these flows contain quartz and interflow hyaloclastitic bands are also present. 
Table 2 (continued).

\begin{tabular}{|c|c|c|c|c|c|c|c|c|c|}
\hline $\begin{array}{l}\text { Core, section } \\
\text { Interval }(\mathrm{cm})\end{array}$ & $\begin{array}{c}92 \mathrm{R}-3(33) \\
55-59\end{array}$ & $\begin{array}{c}93 \mathrm{R}-1(36) \\
96-100\end{array}$ & $\begin{array}{c}96 \mathrm{R}-1(42) \\
77-81\end{array}$ & $\begin{array}{c}96 \mathrm{R}-1(42) \\
77-81\end{array}$ & $\begin{array}{c}86 \mathrm{R}-1(20) \\
128-131\end{array}$ & $\begin{array}{c}86 \mathrm{R}-1(20) \\
128-131\end{array}$ & $\begin{array}{c}86 \mathrm{R}-1(20) \\
128-131\end{array}$ & $\underset{9-12}{88 \mathrm{R}-1}$ & $\underset{9-12}{88 \mathrm{R}-1}$ \\
\hline $\begin{array}{l}\mathrm{SiO} 2 \\
\mathrm{Al} 2 \mathrm{O} 3 \\
\mathrm{TiO} 2 \\
\mathrm{FeO} \\
\mathrm{MgO} \\
\mathrm{CaO} \\
\mathrm{MnO} \\
\mathrm{Cr} 2 \mathrm{O} 3 \\
\mathrm{Na} 2 \mathrm{O}\end{array}$ & $\begin{array}{r}53.40 \\
2.30 \\
0.11 \\
6.03 \\
17.90 \\
20.16 \\
0.14 \\
0.36 \\
0.23\end{array}$ & $\begin{array}{r}53.40 \\
1.80 \\
0.10 \\
5.25 \\
18.38 \\
20.77 \\
0.05 \\
0.46 \\
0.12\end{array}$ & $\begin{array}{r}54.01 \\
1.20 \\
0.04 \\
4.66 \\
19.23 \\
19.84 \\
0.16 \\
0.56 \\
0.15\end{array}$ & $\begin{array}{r}53.32 \\
1.96 \\
0.15 \\
6.03 \\
17.61 \\
20.34 \\
0.28 \\
0.19 \\
0.13\end{array}$ & $\begin{array}{r}53.39 \\
1.39 \\
0.14 \\
8.03 \\
16.35 \\
19.78 \\
0.14 \\
0.22 \\
0.16\end{array}$ & $\begin{array}{r}53.86 \\
1.59 \\
0.19 \\
7.78 \\
16.12 \\
19.66 \\
0.28 \\
0.21 \\
0.24\end{array}$ & $\begin{array}{r}53.97 \\
1.42 \\
0.17 \\
8.26 \\
16.69 \\
18.94 \\
0.24 \\
0.25 \\
0.12\end{array}$ & $\begin{array}{r}53.53 \\
1.91 \\
0.08 \\
4.22 \\
18.57 \\
20.77 \\
0.16 \\
0.90 \\
0.23\end{array}$ & $\begin{array}{r}53.70 \\
2.08 \\
0.20 \\
7.03 \\
17.05 \\
19.44 \\
0.19 \\
0.21 \\
0.24\end{array}$ \\
\hline Total & 100.63 & 100.33 & 99.85 & 100.01 & 99.60 & 99.93 & 100.06 & 100.37 & 100.01 \\
\hline $\begin{array}{l}\% \text { En } \\
\% \mathrm{Fs} \\
\% \mathrm{Wo}\end{array}$ & $\begin{array}{r}49.9 \\
9.7 \\
40.9\end{array}$ & $\begin{array}{r}50.7 \\
8.2 \\
41.1\end{array}$ & $\begin{array}{c}53.1 \\
7.50 \\
39.40\end{array}$ & $\begin{array}{r}49.2 \\
9.9 \\
40.9\end{array}$ & $\begin{array}{l}46.5 \\
13.0 \\
40.5\end{array}$ & $\begin{array}{l}46.4 \\
13.0 \\
40.6\end{array}$ & $\begin{array}{l}47.6 \\
13.6 \\
38.8\end{array}$ & $\begin{array}{r}51.6 \\
6.8 \\
41.6\end{array}$ & $\begin{array}{l}48.6 \\
11.6 \\
39.8\end{array}$ \\
\hline $\begin{array}{l}\text { XFe } \\
\text { AllV } \\
\text { AlVl } \\
\text { Ti }+\mathrm{Cr} \\
\mathrm{Ca}+\mathrm{Na}\end{array}$ & $\begin{array}{l}0.159 \\
0.060 \\
0.039 \\
0.013 \\
0.801\end{array}$ & $\begin{array}{l}0.138 \\
0.057 \\
0.020 \\
0.016 \\
0.818\end{array}$ & $\begin{array}{l}0.120 \\
0.036 \\
0.015 \\
0.017 \\
0.784\end{array}$ & $\begin{array}{l}0.161 \\
0.049 \\
0.036 \\
0.009 \\
0.806\end{array}$ & $\begin{array}{l}0.216 \\
0.026 \\
0.035 \\
0.010 \\
0.795\end{array}$ & $\begin{array}{l}0.213 \\
0.019 \\
0.05 \\
0.011 \\
0.792\end{array}$ & $\begin{array}{l}0.217 \\
0.018 \\
0.043 \\
0.012 \\
0.754\end{array}$ & $\begin{array}{l}0.113 \\
0.059 \\
0.023 \\
0.028 \\
0.823\end{array}$ & $\begin{array}{l}0.188 \\
0.039 \\
0.051 \\
0.012 \\
0.780\end{array}$ \\
\hline Rock type & $\begin{array}{l}\text { Fresh } \\
\text { phenocryst } \\
\text { rim } \\
\text { Type II }\end{array}$ & $\begin{array}{l}\text { Fresh } \\
\text { phenocryst } \\
\text { core } \\
\text { Type II }\end{array}$ & $\begin{array}{l}\text { Fresh } \\
\text { phenocryst } \\
\text { core } \\
\text { Type II }\end{array}$ & $\begin{array}{l}\text { Fresh } \\
\text { phenocryst } \\
\text { rim } \\
\text { Type II }\end{array}$ & $\begin{array}{l}\text { Fresh } \\
\text { phenocryst } \\
\text { core } \\
\text { Type III }\end{array}$ & $\begin{array}{l}\text { Fresh } \\
\text { phenocryst } \\
\text { intermediate } \\
\text { Type III }\end{array}$ & $\begin{array}{l}\text { Fresh } \\
\text { phenocryst } \\
\text { rim } \\
\text { Type III }\end{array}$ & $\begin{array}{l}\text { Fresh } \\
\text { phenocryst } \\
\text { core } \\
\text { Type III }\end{array}$ & $\begin{array}{l}\text { Fresh } \\
\text { phenocryst } \\
\text { rim } \\
\text { Type III }\end{array}$ \\
\hline
\end{tabular}

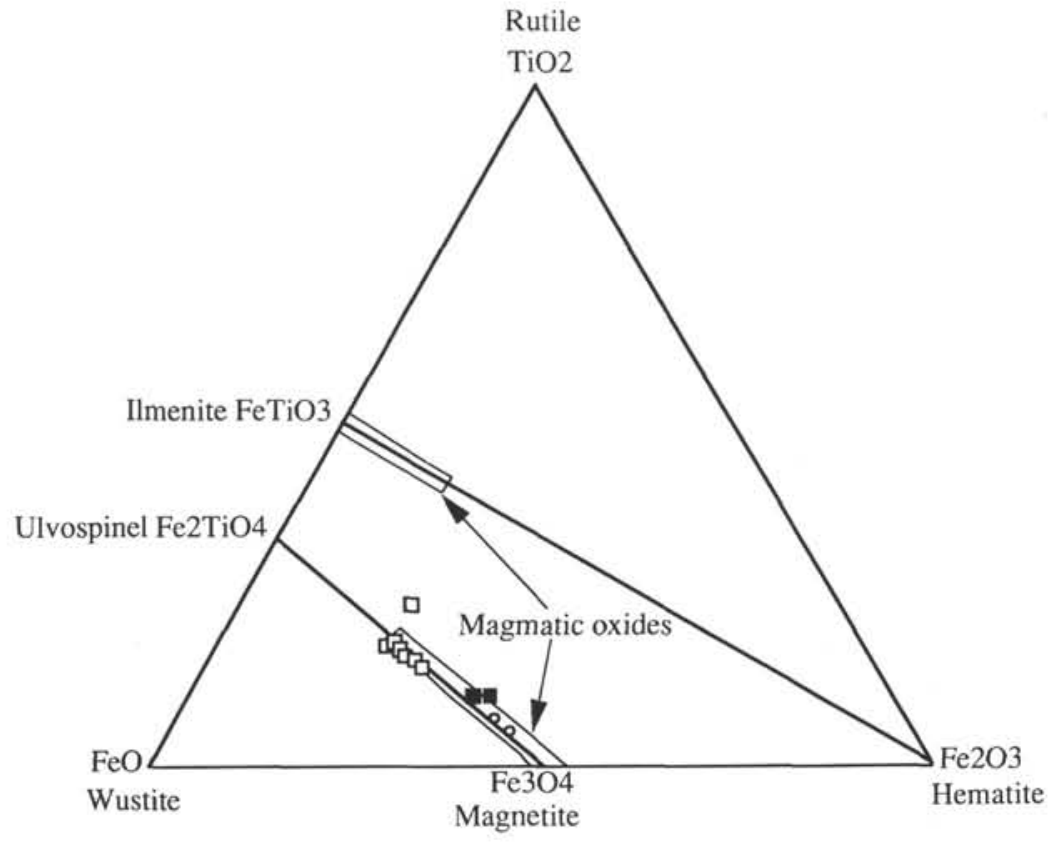

Figure 8. $\mathrm{Fe}$ - $\mathrm{Ti}$ oxide composition in the $\mathrm{TiO}_{2}-\mathrm{FeO}-\mathrm{Fe}_{2} \mathrm{O}_{3}$ diagram, Hole 793B. Open squares $=$ diabase; filled squares $=$ andesitic clasts of the volcaniclastic breccia (Unit VI); and open circles $=$ aphyric to sparsely basaltic andesite (Type iv).

In all the Hole $792 \mathrm{~B}$ andesites, reaction rims around the quartz xenocrysts are systematically absent.

\section{Igneous Mineralogy}

\section{Plagioclases}

Plagioclases (Table 9 and Fig. 10) are the dominant phenocrysts, forming up to 25-40 modal\%). They always include orthopyroxenes, clinopyroxenes, and Fe-Ti oxides. They are either clustered into glomero- porphyritic aggregates that may or may not be associated with pyroxenes, or they mantle large orthopyroxenes pseudomorphs. Oscillatory zoning is common with bytownitic cores $\left(\mathrm{An}_{86-83}\right)$ and labradorite rims $\left(\mathrm{An}_{73-68}\right)$. Locally, the rims may be as $\mathrm{Ca}$-rich as the cores $\left(\mathrm{An}_{81}\right)$. Textural relations demonstrate the progressive Na-enrichment during the crystallization process. Indeed, plagioclases included in the clinopyroxene phenocrysts show anorthitic compositions $\left(\mathrm{An}_{90-87.8}\right)$ whereas, when they are jacketing the orthopyroxenes, they are $\mathrm{Na}$ - enriched $\left(\mathrm{An}_{76-66}\right)$. Microphenocrysts and microlites present in the groundmass display a wide compositional range from $\mathrm{An}_{82}$ to $\mathrm{An}_{65}$. 
Table 2 (continued).

\begin{tabular}{|c|c|c|c|c|c|c|}
\hline $\begin{array}{c}104 \mathrm{R}-1(53) \\
65-70\end{array}$ & $\begin{array}{c}104 R-2(55) \\
64-75\end{array}$ & $\begin{array}{c}104 \mathrm{R}-2(55) \\
64-75\end{array}$ & $\begin{array}{c}109 R-5(71) \\
50-55\end{array}$ & $\begin{array}{c}109 R-5(71) \\
50-55\end{array}$ & $\begin{array}{c}100 R-2(49) \\
16-19\end{array}$ & $\begin{array}{c}114 \mathrm{R}-2(88) \\
35-41\end{array}$ \\
\hline $\begin{array}{r}54.22 \\
1.44 \\
0.12 \\
8.65 \\
15.79 \\
19.04 \\
0.44 \\
0.10 \\
0.20\end{array}$ & $\begin{array}{r}54.53 \\
0.73 \\
0.03 \\
3.91 \\
19.24 \\
20.31 \\
0.13 \\
0.51 \\
0.11\end{array}$ & $\begin{array}{r}52.42 \\
1.93 \\
0.17 \\
8.71 \\
16.14 \\
19.43 \\
0.27 \\
0.29 \\
0.27\end{array}$ & $\begin{array}{r}53.22 \\
2.66 \\
0.12 \\
5.88 \\
16.60 \\
20.02 \\
0.20 \\
0.47 \\
0.13\end{array}$ & $\begin{array}{r}54.92 \\
1.53 \\
0.08 \\
4.22 \\
17.98 \\
19.54 \\
0.20 \\
0.92 \\
0.11\end{array}$ & $\begin{array}{r}54.09 \\
1.46 \\
0.04 \\
5.08 \\
18.15 \\
20.37 \\
0.25 \\
0.48 \\
0.06\end{array}$ & $\begin{array}{r}53.40 \\
2.31 \\
0.09 \\
5.89 \\
16.63 \\
20.05 \\
0.24 \\
0.47 \\
0.09\end{array}$ \\
\hline 100.00 & 99.50 & 99.63 & 99.30 & 99.50 & 99.98 & 99.17 \\
\hline $\begin{array}{l}45.7 \\
14.8 \\
39.5\end{array}$ & $\begin{array}{r}53.3 \\
6.3 \\
40.4\end{array}$ & $\begin{array}{l}45.9 \\
14.3 \\
39.8\end{array}$ & $\begin{array}{r}48.3 \\
9.9 \\
41.8\end{array}$ & $\begin{array}{r}52.1 \\
7.2 \\
40.7\end{array}$ & $\begin{array}{r}50.7 \\
8.4 \\
40.9\end{array}$ & $\begin{array}{l}48.2 \\
10.0 \\
41.0\end{array}$ \\
\hline $\begin{array}{l}0.235 \\
0.004 \\
0.058 \\
0.006 \\
0.775\end{array}$ & $\begin{array}{l}0.102 \\
0.016 \\
0.015 \\
0.016 \\
0.800\end{array}$ & $\begin{array}{l}0.232 \\
0.053 \\
0.032 \\
0.014 \\
0.792\end{array}$ & $\begin{array}{l}0.166 \\
0.044 \\
0.071 \\
0.017 \\
0.797\end{array}$ & $\begin{array}{l}0.116 \\
0.007 \\
0.058 \\
0.028 \\
0.768\end{array}$ & $\begin{array}{l}0.136 \\
0.031 \\
0.032 \\
0.015 \\
0.799\end{array}$ & $\begin{array}{l}0.166 \\
0.035 \\
0.065 \\
0.016 \\
0.796\end{array}$ \\
\hline $\begin{array}{l}\text { Fresh } \\
\text { microphenocryst }\end{array}$ & $\begin{array}{l}\text { Fresh } \\
\text { phenocryst } \\
\text { core } \\
\text { Type III }\end{array}$ & $\begin{array}{l}\text { Fresh } \\
\text { phenocryst } \\
\text { rim } \\
\text { Type III }\end{array}$ & $\begin{array}{l}\text { Fresh } \\
\text { microlite } \\
\text { Type III }\end{array}$ & $\begin{array}{l}\text { Fresh } \\
\text { microphenocryst } \\
\text { Type III }\end{array}$ & $\begin{array}{l}\text { Fresh } \\
\text { microphenocryst } \\
\text { Type IV }\end{array}$ & $\begin{array}{l}\text { Fresh } \\
\text { microphenocryst } \\
\text { Type IV }\end{array}$ \\
\hline
\end{tabular}

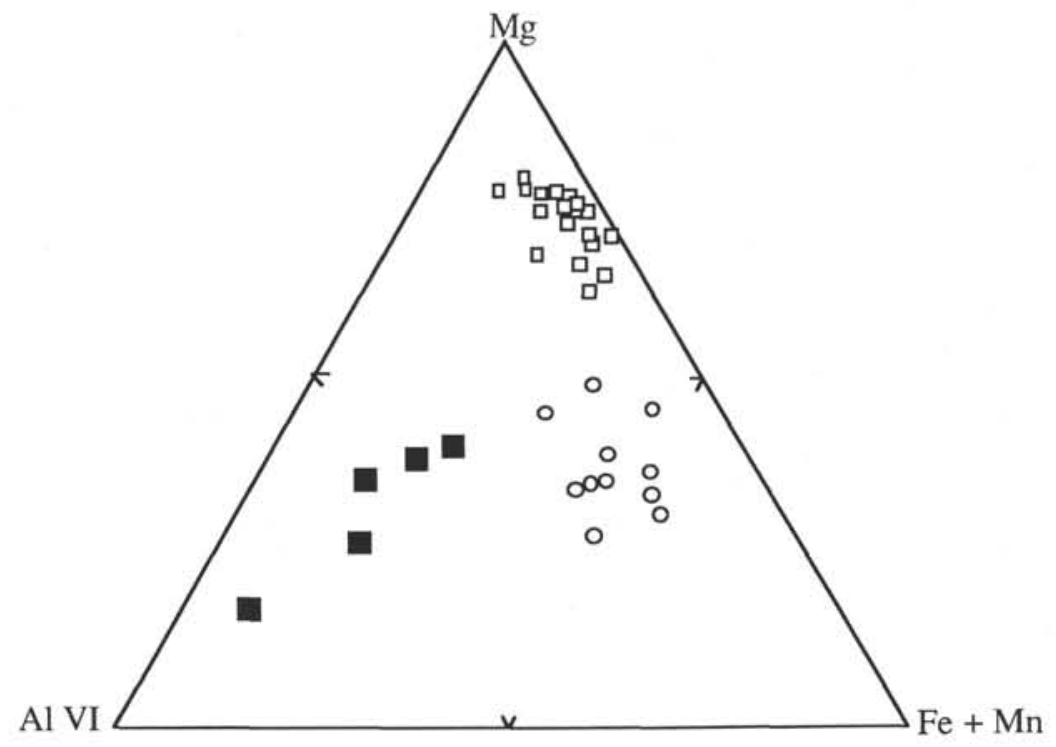

Figure 9. Clay mineral composition in the $\mathrm{Al}^{\mathrm{VI}}-\mathrm{Mg}-\mathrm{Fe}+\mathrm{Mn}$ diagram (after Thorette, 1987), Hole 793B. Filled squares $=$ illite, open squares $=$ saponite, and open circles $=$ celadonite.

\section{Clinopyroxenes}

The clinopyroxenes (Table 10 and Fig. 11) are always fresh and form up to $15 \%$ of the mode. They occur as large phenocrysts either with the plagioclases in glomeroporphyritic aggregates or included in the orthopyroxenes. However, orthopyroxenes are also often jacketed by clinopyroxene microphenocrysts. Despite the visible zoning around the clinopyroxene phenocryst rims, the variations of composition from core to rim are not important and consist of a slight $\mathrm{Fe}$ and $\mathrm{Al}$ enrichment.

The chemical composition of the clinopyroxenes varies with respect to their textural relationship with the orthopyroxene phenocrysts. When they are included in the orthopyroxenes or associated with the plagio- clases, their composition is that of a Fe-rich $(\mathrm{FeO} \approx 17 \%)$ augite. In contrast, they show a $\mathrm{Mg}$ enrichment $(17.15 \%<\mathrm{MgO}<15.60 \%$; $\mathrm{En}_{46.4-49}$ ) and cluster at the limit of the augite-endiopside field (Fig. 11; Poldervaart and Hess, 1951) when they rim the orthopyroxenes.

Such a Mg-enrichment of the clinopyroxenes when they mantle orthopyroxene phenocrysts has been described in calc-alkaline volcanic rocks (Sakuyama, 1979; Fichaut, 1986) and is interpreted to be related to magma mixing.

\section{Titanomagnetites}

Titanomagnetites (Table 11) are widespread in the Hole 792E basement andesites as inclusions in clinopyroxene, orthopyroxene, 
Table 3. Average clinopyroxene compositions of basement, diabase, and breccia (Unit VI) andesites, Marianas boninites, and arc and forearc tholeiites, Hole 793B.

\begin{tabular}{|c|c|c|c|c|c|c|c|c|c|}
\hline Rock type & 1 & II & III & IV & Diabase & Unit VI & Boninite & Arc tholeite & $\begin{array}{c}\text { Forarc lavas } \\
\text { (Leg 59, } \\
\text { Hole 458) }\end{array}$ \\
\hline $\mathrm{SiO}_{2}$ & 54.00 & 53.77 & 53.35 & 54.00 & 53.58 & 52.16 & 51.01 & 48.80 & 52.70 \\
\hline $\mathrm{Al}_{2} \mathrm{O}_{3}$ & 1.74 & 1.75 & 1.78 & 1.86 & 2.24 & 1.83 & 4.53 & 2.41 & 2.30 \\
\hline $\mathrm{TiO}_{2}$ & 0.09 & 0.09 & 0.13 & 0.07 & 0.19 & 0.26 & 0.29 & 0.32 & 0.20 \\
\hline $\mathrm{FeO}$ & 5.27 & 5.39 & 7.12 & 5.57 & 6.65 & 11.14 & - & 9.32 & 9.70 \\
\hline $\mathrm{MgO}$ & 17.75 & 18.02 & 17.28 & 17.40 & 17.83 & 14.94 & 16.93 & 12.78 & 16.25 \\
\hline $\mathrm{CaO}$ & 20.01 & 20.17 & 19.25 & 20.20 & 18.62 & 18.96 & 17.43 & 17.68 & 18.30 \\
\hline $\mathrm{MnO}$ & 0.13 & 0.14 & 0.19 & 0.15 & 0.18 & 0.29 & 0.28 & 0.20 & 0.17 \\
\hline $\mathrm{Cr}_{2} \mathrm{O}_{3}$ & 0.46 & 0.55 & 0.27 & 0.42 & 0.21 & 0.09 & 0.03 & 0.02 & 0.22 \\
\hline $\mathrm{Na}_{2} \mathrm{O}$ & 0.17 & 0.16 & 0.17 & 0.12 & 0.14 & 0.19 & 0.29 & 0.46 & 0.16 \\
\hline$\%$ En & 50.5 & 50.60 & 48.90 & 49.51 & 51.00 & 42.72 & 49.00 & 38.00 & 46.5 \\
\hline$\% \mathrm{Fs}$ & 8.60 & 8.70 & 11.60 & 9.16 & 10.14 & 18.33 & 14.00 & 24.00 & 15.9 \\
\hline$\% W_{0}$ & 40.90 & 40.70 & 39.40 & 41.33 & 38.86 & 38.95 & 37.00 & 38.00 & 37.6 \\
\hline
\end{tabular}

Notes: The structural formulas was calculated on the basis of six oxygenes. The numbers in parentheses correspond to the sample numbers analyzed for major and trace element chemistry (Taylor et al., this volume). Boninite and arc tholeiite-clinopyroxene compositions after Natland (1981); forearc-clinopyroxene compositions after Meijer et al. (1980).

and plagioclases phenocrysts, or as microphenocrysts in the groundmass. Their composition is remarkably constant (Table 11). Their high $\mathrm{TiO}_{2}$ content $\left(8.17 \%<\mathrm{TiO}_{2}<10.3 \%\right.$, Usp $25.5-30.4$; Table 11$)$ is characteristic of titaniferous magnetite (Buddington and Linsley, 1964; Deer et al., 1964, 1980).

The occurrence and composition of titanomagnetites in the Hole $792 \mathrm{E}$ basement andesites resemble the same characteristics of oxides in the andesitic clasts of the volcaniclastic breccia of Hole 793E (Unit VI; Table 6). In both rocks, the titanomagnetites represent an early crystallized phase.

\section{DISCUSSION}

The Izu-Bonin forearc volcanic rocks recovered from Holes 792E and 793B show very different mineralogy and magmatic affinities, but similar secondary mineralogy related to low-grade hydrothermal activity.

The highly porphyritic andesite recovered from Hole 792E is formed of intensely oscillatory zoned plagioclases, Fe-rich augites, orthopyroxene pseudomorphs, titanomagnetites, and local olivine pseudomorphs and quartz. The titanomagnetite is systematically included in the phenocrysts. The presence of a Mg-enrichment in the clinopyroxenes that mantle the orthopyroxene phenocrysts suggest magma mixing. The calc-alkaline feature of these porphyritic andesites is confirmed by their major and trace element chemistry (Taylor, Fujioka, et al., 1990; Taylor et al., this volume). Indeed, the analyzed samples of Hole 792E show an evolutionary trend, typical of calc-alkaline suites with a decline in total iron and titanium, correlated with an increase in $\mathrm{SiO}_{2}$, with decreasing $\mathrm{MgO}$ contents (Taylor, Fujioka, et al., 1990; Taylor et al., this volume). The andesitic clasts of the Hole 793B volcaniclastic breccia (Unit VI) have the same mineralogy as the Hole 792E andesite, and in both rocks, the chemistry of the plagioclases, clinopyroxenes, and titanomagnetites are similar. The early precipitation of titanomagnetites, the high Fe content in the augites, and the intense oscillatory zoning in the plagioclase phenocrysts suggest that these andesites are calc-alkaline. Thus, the basement highly porphyritic andesites, recovered at Hole 792E, and the Hole 793B andesitic clasts of Unit VI show the same petrological and geochemical characteristics, which are that of calc-alkaline suites. These volcanic rocks likely represent the products of Izu-Bonin Arc magmatic activity during Oligocene times.

The Hole 793B middle Neogene diabase sill and basement andesitic lavas are completely different. The diabase sill mineralogy is that of an arc tholeiite with the following crystallization order: olivine (now pseudomorphs), $\mathrm{Mg}$-rich orthopyroxene, $\mathrm{Mg}$-Ca-rich clinopyroxenes (endiopside-augite), Ca-rich plagioclase, and finally, titanomagnetite, the last mineral to crystallize. Its similar petrological and geochemical composition to Toroshima and other Izu Arc volcanoes (Taylor, Fujioka, et al., 1990; Taylor et al., this volume), together with its stratigraphic position and age, allow this diabase intrusion to be considered as related to Izu-Bonin Arc magmatic activity.
The very homogeneous composition of the plagioclase, clinopyroxene, and orthopyroxene phenocrysts in all the Hole 793B tasement basaltic andesites suggests that the petrological differences between the four lava types are linked to processes of crystal fractionation and accumulation. Indeed, the chemistry of the bronzite phenocrysts is constant in all the lava types. The behavior of $\mathrm{Cr}, \mathrm{Mg}$, $\mathrm{Al}$, and $\mathrm{Ti}$, relative to $\mathrm{XFe}$ (differentiation index) in the clinopyroxene phenocrysts suggests that the petrological differences between andesite Types $i$ and iii are related to crystal fractionation. The petrological differences between lava Types $\mathrm{i}$ and ii, and Types iii and iv, which consist mainly of a difference in the modal proportions of the pyroxenes and plagioclases respectively, are likely a result of clinopyroxene and/or plagioclase accumulation. Taylor et al. (this volume) have shown that (1) the whole-rock compositions of the Hole 793B basaltic andesites depend on both the phenocryst abundance and the magma evolution, and (2) these rocks have uniquely consistent ${ }^{143} \mathrm{Nd} /{ }^{144} \mathrm{Nd}$ ratios, with an $\varepsilon_{\mathrm{Nd}}$ ranging from 5.63 to $6.82(\mathrm{~T}=30 \mathrm{Ma})$. These results suggest that the Hole 793B basaltic andesites are cogenetic. Our data on the clinopyroxene chemistry support these conclusions.

The Hole 793B basaltic andesites show intermediate features between arc tholeiites and boninites. Their crystallization sequence is that of an arc tholeiite but their petrology and mineral chemistry show similarities with boninites: $\mathrm{Cr}$-spinel in olivine, and the presence of $\mathrm{Mg}$-rich bronzite that is commonly rimmed by $\mathrm{Ca}-\mathrm{Mg}$-rich endiopside augite. They differ by containing Ca-plagioclase as phenocrysts in all rock types but Type i lavas. Moreover, they exhibit transitional trace element depletion and $\varepsilon_{\mathrm{Nd}}$ ratios between arc tholeiites and boninites (Taylor et al., this volume).

The Hole 793B basement lavas from the Izu-Bonin Arc and Site 458 bronzite andesites from the Mariana forearc are similar in most respects. They have the same forearc tectonic setting (Hussong and Uyeda, 1982; Taylor, Fujioka, et al., 1990). They are dated as mid to late Oligocene (Tagikami and Osima, 1982; Taylor and Mitchell, this volume). Their petrology and mineralogy are similar (Meijer et al., 1982; Natland, 1982). Finally, they show identical geochemical (Bougault et al., 1982; Hickey and Frey, 1982; Taylor et al., this volume) and isotopic characteristics (Hickey-Vargas, 1989; Taylor et al., this volume).

Thus, the syn-rift magmatism related to extension of the forearc of the Izu-Bonin and Mariana arcs is represented by the Hole 793B basement andesites and the Site 458 andesites that belong to an island-arc-depleted tholeiitic suite, displaying boninitic affinities. The Hole 792E calc-alkaline andesites, apparently somewhat older at 30-32 Ma (Taylor and Mitchell, this volume), may represent the remnants of a pre-extensional phase of normal arc magmatism.

The low-grade hydrothermal alteration was the result of the interaction of seawater with the igneous rocks. This is clearly shown by the high values of $\varepsilon_{\mathrm{Sr}}$ ( -11.26 to $-3.41 ; T=30 \mathrm{Ma}$; Taylor et al., this volume). Evidence for the hydrothermal activity comes from saponite-celadonite pseudomorphs of olivine, the illite or saponite + celadonite replacement of glass, and the presence of heulandite in vesicles, veins, and cracks. 

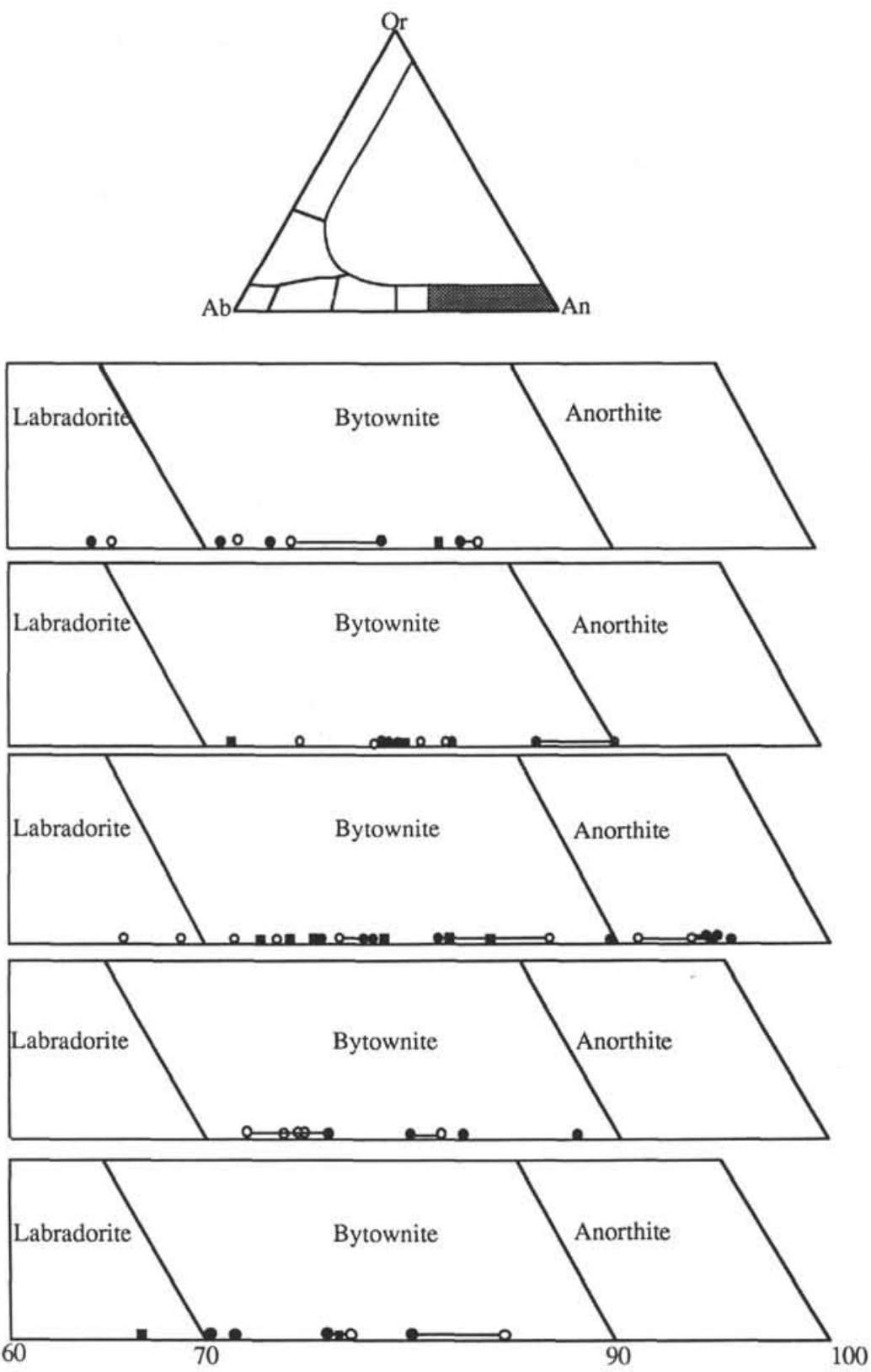

An \%

Figure 10. Andesite-plagioclase composition in the orthoclase (Or)-albite (Ab)-anorthite (An) diagram (after Deer et al., 1964, 1980), Hole 792E. Filled squares $=$ microphenocrysts and microlites, filled circles $=$ phenocryst core, and open circles $=$ phenocryst rim.

This alteration took place under very low pressures and temperatures $\left(<100^{\circ} \mathrm{C}\right)$ and provoked the anomalous P, Y, and rare-earth-element concentrations relative to high-field-strength elements in some flows recovered from Holes 793B and 792E (Taylor et al., this volume).

\section{REFERENCES}

Boles, J. R., 1972. Compositions, optical properties, cell dimensions and thermal stability of some heulandite-group zeolites. Am. Min., 57:1463-1493.

, 1977. Zeolites in low-grade metamorphic grades. In Mumpton,

F. A. (Ed.), Mineralogy and Geology of Natural Zeolites (Vol. 4):

Blacksburg, VA (Southern Printing), 103-135.

Bougault, H., Maury, R. C., El Azzoui, M., Joron, J. L., Cotten, J., and Treuil, M., 1982. Tholeiites, basaltic andesites, and andesites from Leg 60 Sites: geochemistry, mineralogy, and low partition coefficient elements. In Hussong, D. M., Uyeda, S., et al., Init. Repts. DSDP, 60: Washington (U.S. Govt. Printing Office), 657-666.

Buddington, A. F., and Linsley, D. H., 1964. Iron-titanium oxides minerals and synthetic equivalents. J. Petrol., 5:310-357.

Cameron, W. E., McCulloch, M. T., and Walker, D. A., 1983. Boninites petrogenesis: chemical and Nd-Sr isotopic constraints. Earth Planet. Sci. Lett., 65:75-89.

Cameron, W. E., Nisbet, E. G., and Dietrich, V. J., 1979. Boninites, komatiites, and ophiolitic basalts. Nature, 280:550-553.

Coombs, D. S., 1963. Trends and affinities of basaltic magmas and pyroxenes as illustrated on the diopside-olivin-silica diagram. Mineral. Soc. Am. Spec. Pap., 1:227-250.

Deer, W. A., Howie, R. A., and Zussmann, J., 1964. Rock-forming Minerals (Vols. 1-5): London (Longman Group Ltd.). 
Table 4. Basement andesite-orthopyroxene representative compositions, Hole 793B.

\begin{tabular}{|c|c|c|c|c|c|c|c|c|c|c|c|c|}
\hline $\begin{array}{l}\text { Core, section } \\
\text { Interval }(\mathrm{cm})\end{array}$ & $\begin{array}{c}110 R-3(75) \\
78-83\end{array}$ & $\underset{78-83}{110 R-3}(75)$ & $\begin{array}{c}93 R-1(36) \\
63-67\end{array}$ & $\begin{array}{c}93 R-1(36) \\
63-67\end{array}$ & $\underset{70-74}{92 R-2(30)}$ & $\begin{array}{c}92 \mathrm{R}-2(30) \\
70-74\end{array}$ & $\begin{array}{c}92 R-2(31) \\
113-117\end{array}$ & $\begin{array}{c}92 \mathrm{R}-2(31) \\
113-117\end{array}$ & $\underset{55-59}{92 R-3(33)}$ & $\begin{array}{c}92 \mathrm{R}-3(33) \\
55-59\end{array}$ & $\underset{57-62}{112 R-2}$ & $\underset{57-62}{112 R-2(83)}$ \\
\hline $\begin{array}{l}\mathrm{SiO}_{2} \\
\mathrm{Al}_{2} \mathrm{O}_{3} \\
\mathrm{TiO}_{2} \\
\mathrm{FeO} \\
\mathrm{MgO} \\
\mathrm{CaO} \\
\mathrm{MnO} \\
\mathrm{Cr}_{2} \mathrm{O}_{3} \\
\mathrm{Na}_{2} \mathrm{O}\end{array}$ & $\begin{array}{r}55.57 \\
1.18 \\
0.08 \\
10.11 \\
30.92 \\
1.83 \\
0.13 \\
0.21 \\
-\end{array}$ & $\begin{array}{r}55.07 \\
1.51 \\
0.00 \\
10.67 \\
30.85 \\
2.02 \\
0.42 \\
0.34 \\
0.06\end{array}$ & $\begin{array}{r}56.34 \\
1.14 \\
0.08 \\
10.02 \\
30.88 \\
1.76 \\
0.12 \\
0.29 \\
0.06\end{array}$ & $\begin{array}{r}56.29 \\
1.09 \\
0.11 \\
9.77 \\
31.53 \\
1.67 \\
0.22 \\
-0.02\end{array}$ & $\begin{array}{r}57.03 \\
1.06 \\
0.08 \\
9.14 \\
31.15 \\
1.81 \\
0.25 \\
0.35 \\
0.05\end{array}$ & $\begin{array}{r}57.28 \\
0.72 \\
0.00 \\
8.93 \\
31.41 \\
1.95 \\
0.27 \\
\overline{0} .08\end{array}$ & $\begin{array}{r}56.13 \\
1.18 \\
0.03 \\
10.09 \\
30.22 \\
1.91 \\
0.22 \\
0.26 \\
0.01\end{array}$ & $\begin{array}{r}56.52 \\
1.32 \\
0.03 \\
10.56 \\
29.77 \\
1.63 \\
0.12 \\
0.34 \\
-\end{array}$ & $\begin{array}{r}57.45 \\
0.43 \\
0.02 \\
8.00 \\
32.28 \\
2.00 \\
0.15 \\
0.24 \\
0.04\end{array}$ & $\begin{array}{r}56.47 \\
1.38 \\
0.11 \\
10.57 \\
29.83 \\
1.84 \\
0.33 \\
0.14 \\
0.03\end{array}$ & $\begin{array}{r}56.65 \\
1.07 \\
0.07 \\
9.62 \\
31.21 \\
1.76 \\
0.17 \\
0.05 \\
-\end{array}$ & $\begin{array}{r}56.83 \\
0.88 \\
- \\
9.72 \\
30.72 \\
1.71 \\
0.21 \\
0.07 \\
-\end{array}$ \\
\hline Total & 100.03 & 100.94 & 100.69 & 100.70 & 100.92 & 100.64 & 100.05 & 100.29 & 100.61 & 100.70 & 100.60 & 100.14 \\
\hline $\begin{array}{l}\% \text { En } \\
\% \mathrm{Fs} \\
\% W_{0}\end{array}$ & $\begin{array}{r}81.40 \\
15.10 \\
3.50\end{array}$ & $\begin{array}{r}80.10 \\
16.20 \\
3.70\end{array}$ & $\begin{array}{r}81.60 \\
15.00 \\
3.40\end{array}$ & $\begin{array}{r}82.2 \\
14.6 \\
3.2\end{array}$ & $\begin{array}{c}82.6 \\
14.0 \\
3.40\end{array}$ & $\begin{array}{r}82.7 \\
13.6 \\
3.7\end{array}$ & $\begin{array}{r}80.8 \\
15.5 \\
3.7\end{array}$ & $\begin{array}{r}80.6 \\
16.2 \\
3.2\end{array}$ & $\begin{array}{r}84.3 \\
11.9 \\
3.6\end{array}$ & $\begin{array}{r}80.0 \\
16.4 \\
3.5\end{array}$ & $\begin{array}{r}82.2 \\
14.5 \\
3.3\end{array}$ & $\begin{array}{r}81.9 \\
14.9 \\
3.2\end{array}$ \\
\hline $\begin{array}{l}\text { XFe } \\
\text { AlIV } \\
\text { AlVI }\end{array}$ & $\begin{array}{l}0.155 \\
0.041 \\
0.008\end{array}$ & $\begin{array}{l}0.163 \\
0.063 \\
-\end{array}$ & $\begin{array}{l}0.154 \\
0.030 \\
0.017\end{array}$ & $\begin{array}{l}0.148 \\
0.035 \\
0.010\end{array}$ & $\begin{array}{l}0.141 \\
0.019 \\
0.024\end{array}$ & $\begin{array}{l}0.138 \\
0.008 \\
0.022\end{array}$ & $\begin{array}{l}0.158 \\
0.024 \\
0.025\end{array}$ & $\begin{array}{l}0.166 \\
0.015 \\
0.040\end{array}$ & $\begin{array}{l}0.122 \\
0.010 \\
0.006\end{array}$ & $\begin{array}{l}0.166 \\
0.022 \\
0.035\end{array}$ & $\begin{array}{l}0.147 \\
0.023 \\
0.021\end{array}$ & $\begin{array}{l}0.151 \\
0.009 \\
0.027\end{array}$ \\
\hline Rock type & $\begin{array}{l}\text { Fresh } \\
\text { phenocryst } \\
\text { core } \\
\text { Type I }\end{array}$ & $\begin{array}{l}\text { Fresh } \\
\text { phenocryst } \\
\text { rim } \\
\text { Type I }\end{array}$ & $\begin{array}{l}\text { Fresh } \\
\text { phenocryst } \\
\text { core } \\
\text { Type I }\end{array}$ & $\begin{array}{l}\text { Fresh } \\
\text { phenocryst } \\
\text { rim } \\
\text { Type I }\end{array}$ & $\begin{array}{l}\text { Fresh } \\
\text { phenocryst } \\
\text { core } \\
\text { Type II }\end{array}$ & $\begin{array}{l}\text { Fresh } \\
\text { phenocryst } \\
\text { rim } \\
\text { Type II }\end{array}$ & $\begin{array}{l}\text { Fresh } \\
\text { phenocryst } \\
\text { core } \\
\text { Type II }\end{array}$ & $\begin{array}{l}\text { Fresh } \\
\text { phenocryst } \\
\text { rim } \\
\text { Type II }\end{array}$ & $\begin{array}{l}\text { Fresh } \\
\text { phenocryst } \\
\text { core } \\
\text { Type II }\end{array}$ & $\begin{array}{l}\text { Fresh } \\
\text { phenocryst } \\
\text { rim } \\
\text { Type II }\end{array}$ & $\begin{array}{l}\text { Fresh } \\
\text { phenocryst } \\
\text { core } \\
\text { Type II }\end{array}$ & $\begin{array}{l}\text { Fresh } \\
\text { phenocryst } \\
\text { rim } \\
\text { Type II }\end{array}$ \\
\hline
\end{tabular}
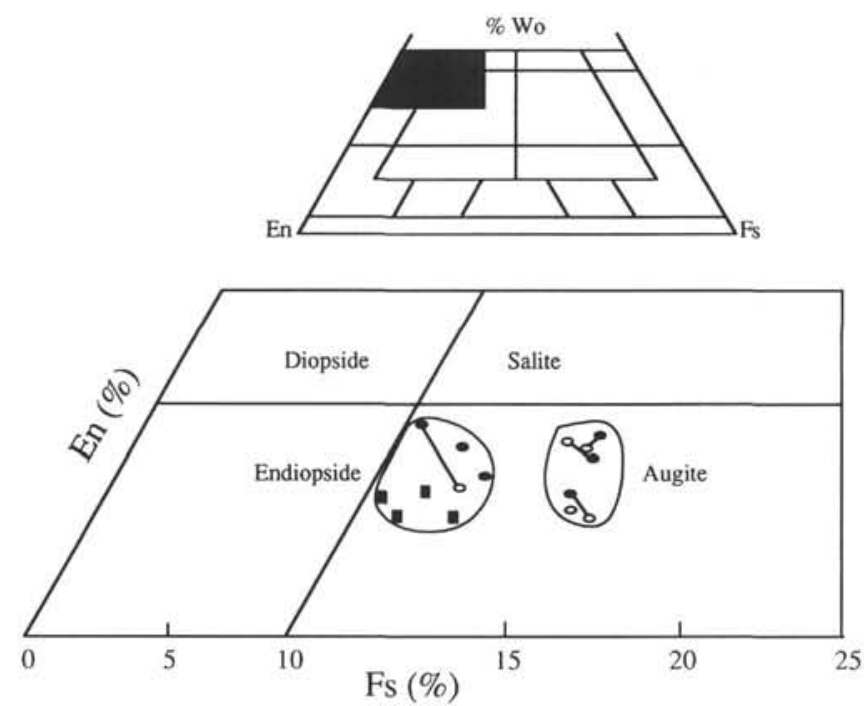

Figure 11. Andesite-clinopyroxene composition in the wollastonite (Wo)-enstatite (En)-ferrosilite (Fs) diagram (after Poldervaart and Hess, 1951), Hole 792E. Filled squares $=$ clinopyroxene-microphenocryst rims around orthopyroxene, filled circles $=$ phenocryst cores, and open circles $=$ phenocryst rims.
, 1978. Rock-forming Minerals (Vol. 2A): Single-chain Silicates (2d ed.): London (Longman Group Ltd.).

, 1980. An Introduction to the Rock-forming Minerals: London (Longman Group Ltd.).

Dick, H.J.B., and Bullen, T., 1984. Chromian spinel as a petrogenetic indicator in abyssal and alpine-type peridotites and spatially associated lavas. Contrib. Mineral. Petrol., 86:54-76.

Duplay, J., and Buatier, M., 1990. The problem of differentiation of glauconite and celadonite. Chem. Geol., 84:264-266.

Fichaut, M., 1986. Magmatologie de la Montagne Pelée (Martinique) [Thèse de doctorat]. Univ. de Brest, France.

Gasparik, T., 1984. Two pyroxene barometry with new experimental data in the system $\mathrm{CaO}-\mathrm{MgO}-\mathrm{Al}_{2} \mathrm{O}_{3}-\mathrm{SiO}_{2}$. Contrib. Mineral. Petrol., 87:87-94.

Gibbs, G. P., 1973. The zoned pyroxenes of the Shiant Isles sill, Scotland. J. Petrol., 4:203-230.

Gill, J. B., 1981. Minerals and Rocks (Vol. 16): Orogenic Andesites and Plate Tectonics: Berlin (Springer-Verlag).

Groove, T. L., and Bence, A. E., 1977. Experimental study of clinopyroxeneliquid-interaction in quartz normative basalt 15597. Proc. 8th Lunar Sci. Conf., 18.

Hénoc, J., and Tong, M., 1978. Automatization de la microsonde. J. Microsc. Spectrosc. Electron., 3:247-254.

Herzberg, C. T., 1978. Pyroxene geothermobarometry and geobarometry: experimental and thermodynamic evaluation of some solidus phase relations involving pyroxenes in the system $\mathrm{CaO}-\mathrm{MgO}-\mathrm{Al}_{2} \mathrm{O}_{3}-\mathrm{SiO}_{2}$, Geochim. Cosmochim. Acta, 42:945-957.

Hickey, R. L., and Frey, F. A., 1982. Rare-earth element geochemistry of Mariana forearc volcanics: Deep Sea Drilling Project Site 458 and Hole

Table 5. Basement andesite Cr-spinel compositions, Hole 793B.

\begin{tabular}{|c|c|c|c|c|c|c|}
\hline $\begin{array}{l}\text { Core, section } \\
\text { Interval in cm }\end{array}$ & $\begin{array}{c}93 R-1(36) \\
96-100\end{array}$ & $\begin{array}{c}93 \mathrm{R}-1(36) \\
96-100\end{array}$ & $\begin{array}{c}99 \mathrm{R}-1(48) \\
140-144\end{array}$ & $\begin{array}{c}100 \mathrm{R}-2(49) \\
16-19\end{array}$ & $\underset{50-55}{109 \mathrm{R}-8(71)}$ & $\begin{array}{c}112 \mathrm{R}-2(83) \\
57-62\end{array}$ \\
\hline $\begin{array}{l}\mathrm{TiO}_{2} \\
\mathrm{Al}_{2} \mathrm{O}_{3} \\
\mathrm{Cr}_{2} \mathrm{O}_{3} \\
\mathrm{FeO}^{*} \\
\mathrm{MnO} \\
\mathrm{MgO}\end{array}$ & $\begin{array}{r}0.12 \\
5.99 \\
69.93 \\
24.49 \\
0.27 \\
8.94\end{array}$ & $\begin{array}{r}0.15 \\
6.78 \\
67.64 \\
25.66 \\
0.27 \\
8.73\end{array}$ & $\begin{array}{r}0.28 \\
8.87 \\
50.21 \\
27.65 \\
0.18 \\
9.84\end{array}$ & $\begin{array}{r}0.23 \\
5.42 \\
57.38 \\
23.95 \\
0.23 \\
8.96\end{array}$ & $\begin{array}{r}0.25 \\
9.01 \\
52.17 \\
26.26 \\
0.27 \\
26.26\end{array}$ & $\begin{array}{r}0.16 \\
10.87 \\
50.88 \\
33.48 \\
0.36 \\
8.64\end{array}$ \\
\hline Total & 109.74 & 109.23 & 97.03 & 96.17 & 95.96 & 104.39 \\
\hline $\begin{array}{l}\mathrm{Fe}_{2} \mathrm{O}_{3} \\
\mathrm{FeO}\end{array}$ & $\begin{array}{r}2.38 \\
22.34\end{array}$ & $\begin{array}{r}3.22 \\
22.67\end{array}$ & $\begin{array}{l}11.03 \\
17.72\end{array}$ & $\begin{array}{r}6.53 \\
18.08\end{array}$ & $\begin{array}{r}6.92 \\
20.03\end{array}$ & $\begin{array}{l}12.78 \\
21.98\end{array}$ \\
\hline $\begin{array}{l}\text { \%Magnetite } \\
\% \text { Hercynite } \\
\% \text { Chromium spinel }\end{array}$ & $\begin{array}{r}2.8 \\
11.0 \\
86.2\end{array}$ & $\begin{array}{r}3.9 \\
12.5 \\
83.6\end{array}$ & $\begin{array}{l}14.2 \\
17.9 \\
67.9\end{array}$ & $\begin{array}{r}8.7 \\
11.3 \\
80.0\end{array}$ & $\begin{array}{r}9.1 \\
18.6 \\
72.3\end{array}$ & $\begin{array}{l}15.4 \\
20.5 \\
64.1\end{array}$ \\
\hline $\begin{array}{l}\text { Occurrence } \\
\text { Rock type }\end{array}$ & $\begin{array}{l}\text { Olivine } \\
\text { Type I }\end{array}$ & $\begin{array}{l}\text { Olivine } \\
\text { Type I }\end{array}$ & $\begin{array}{l}\text { Olivine } \\
\text { Type I }\end{array}$ & $\begin{array}{l}\text { Groundmass } \\
\text { Type IV }\end{array}$ & $\begin{array}{l}\text { Groundmass } \\
\text { Type III }\end{array}$ & $\begin{array}{l}\text { Orthopyroxene } \\
\text { Type fI }\end{array}$ \\
\hline
\end{tabular}


Table 6. Igneous rock Fe-Ti oxide compositions, Hole 793B.

\begin{tabular}{|c|c|c|c|c|c|}
\hline $\begin{array}{l}\text { Core, section } \\
\text { Interval }(\mathrm{cm})\end{array}$ & $\begin{array}{l}1 R-1(4) \\
132-136\end{array}$ & $\underset{61-65}{\operatorname{IR}-2(7)}$ & $\begin{array}{c}85 R-2(18) \\
49-53\end{array}$ & $\begin{array}{c}85 R-2(18) \\
49-53\end{array}$ & $\underset{57-62}{112 R-2(83)}$ \\
\hline $\begin{array}{l}\mathrm{TiO}_{2} \\
\mathrm{Al}_{2} \mathrm{O}_{3} \\
\mathrm{Cr}_{2} \mathrm{O}_{3} \\
\mathrm{FeO}^{*} \\
\mathrm{MnO} \\
\mathrm{MgO}\end{array}$ & $\begin{array}{r}15.05 \\
2.51 \\
0.06 \\
77.43 \\
0.24 \\
0.69\end{array}$ & $\begin{array}{r}15.43 \\
2.17 \\
0.00 \\
75.74 \\
0.31 \\
0.46\end{array}$ & $\begin{array}{r}6.61 \\
2.70 \\
0.09 \\
77.76 \\
0.21 \\
2.25\end{array}$ & $\begin{array}{r}7.69 \\
1.69 \\
0.09 \\
65.39 \\
0.35 \\
0.33\end{array}$ & $\begin{array}{r}3.56 \\
2.35 \\
0.04 \\
86.93 \\
0.07 \\
0.79\end{array}$ \\
\hline Total & 95.98 & 93.98 & 89.62 & 75.54 & 93.74 \\
\hline $\begin{array}{l}\mathrm{Fe}_{2} \mathrm{O}_{3} \\
\mathrm{FeO}\end{array}$ & $\begin{array}{l}37.07 \\
44.07\end{array}$ & $\begin{array}{l}35.09 \\
44.17\end{array}$ & $\begin{array}{l}50.49 \\
33.39\end{array}$ & $\begin{array}{l}37.98 \\
32.21\end{array}$ & $\begin{array}{l}59.92 \\
33.38\end{array}$ \\
\hline $\begin{array}{l}\text { \%Magnetite } \\
\text { \% Hercynite } \\
\text { \% Ulvöspinel }\end{array}$ & $\begin{array}{c}90.3 \\
9.6 \\
44.81\end{array}$ & $\begin{array}{c}91.2 \\
8.8 \\
41.13\end{array}$ & $\begin{array}{c}90.5 \\
9.1 \\
28.85\end{array}$ & $\begin{array}{c}93.3 \\
6.5 \\
33.01\end{array}$ & $\begin{array}{c}94.1 \\
5.8 \\
17.58\end{array}$ \\
\hline $\begin{array}{l}\text { Occurrence } \\
\text { Rock type }\end{array}$ & $\begin{array}{l}\text { Groundmass } \\
\text { Diabase }\end{array}$ & $\begin{array}{l}\text { Groundmass } \\
\text { Diabase }\end{array}$ & $\begin{array}{l}\text { Clinopyroxene } \\
\text { Unit } \mathrm{V}\end{array}$ & $\begin{array}{l}\text { Clinopyroxene } \\
\text { Unit } \mathrm{VI}\end{array}$ & $\begin{array}{l}\text { Groundmass } \\
\text { Type II }\end{array}$ \\
\hline
\end{tabular}

Table 7. Clay-mineral representative compositions, Hole 793B.

\begin{tabular}{|c|c|c|c|c|c|c|c|c|c|c|c|c|}
\hline $\begin{array}{l}\text { Core, section } \\
\text { Interval (cm) }\end{array}$ & $\begin{array}{l}1 R-1(4) \\
132-136\end{array}$ & $\begin{array}{c}\text { IR-2 (7) } \\
61-65\end{array}$ & $\underset{70-74}{92 R-2(30)}$ & $\begin{array}{c}93 R-1(36) \\
96-100\end{array}$ & $\begin{array}{c}110 R-4(75) \\
78-83\end{array}$ & $\begin{array}{c}93 R-1(36) \\
96-100\end{array}$ & $\begin{array}{c}96 R-1 \text { (42) } \\
77-81\end{array}$ & $\underset{50-55}{109 R-8(71)}$ & $\begin{array}{c}\text { 100R-2 (49) } \\
16-19\end{array}$ & $\begin{array}{c}100 R-2(49) \\
16-19\end{array}$ & $\begin{array}{c}96 \mathrm{R}-1 \text { (42) } \\
77-81\end{array}$ & $\begin{array}{c}109 \mathrm{R}-8(71) \\
50-55\end{array}$ \\
\hline $\begin{array}{l}\mathrm{SiO}_{2} \\
\mathrm{Al}_{2} \mathrm{O}_{3} \\
\mathrm{TiO}_{2} \\
\mathrm{FeO} \\
\mathrm{MgO} \\
\mathrm{MnO} \\
\mathrm{CaO} \\
\mathrm{Na}_{2} \mathrm{O} \\
\mathrm{K}_{2} \mathrm{O} \\
\mathrm{Cr}_{2} \mathrm{O}_{3}\end{array}$ & $\begin{array}{r}51.70 \\
3.98 \\
0.00 \\
9.11 \\
19.94 \\
0.32 \\
0.33 \\
0.37 \\
0.71\end{array}$ & $\begin{array}{r}54.00 \\
1.93 \\
0.00 \\
6.82 \\
18.94 \\
0.14 \\
0.32 \\
0.49 \\
0.92 \\
0.08\end{array}$ & $\begin{array}{r}51.90 \\
5.02 \\
0.00 \\
8.66 \\
21.01 \\
0.16 \\
1.57 \\
0.07 \\
0.04 \\
-\end{array}$ & $\begin{array}{r}48.80 \\
5.12 \\
0.04 \\
7.11 \\
19.65 \\
0.26 \\
0.61 \\
0.20 \\
0.49 \\
-\end{array}$ & $\begin{array}{r}42.67 \\
3.85 \\
0.02 \\
14.79 \\
17.83 \\
0.21 \\
1.36 \\
0.17 \\
0.88 \\
0.05\end{array}$ & $\begin{array}{r}56.01 \\
5.95 \\
0.13 \\
12.78 \\
9.85 \\
0.13 \\
0.14 \\
0.06 \\
8.33 \\
0.05\end{array}$ & $\begin{array}{r}55.59 \\
4.46 \\
0.11 \\
15.40 \\
7.38 \\
0.02 \\
0.09 \\
0.03 \\
8.72 \\
0.11\end{array}$ & $\begin{array}{r}56.57 \\
5.29 \\
0.01 \\
16.26 \\
7.20 \\
0.18 \\
1.25 \\
0.15 \\
4.95 \\
0.15\end{array}$ & $\begin{array}{r}55.72 \\
5.28 \\
0.30 \\
13.40 \\
6.10 \\
0.02 \\
0.18 \\
0.03 \\
9.65 \\
0.10\end{array}$ & $\begin{array}{r}49.80 \\
13.36 \\
0.15 \\
5.67 \\
4.44 \\
0.08 \\
3.68 \\
2.13 \\
1.35 \\
-\end{array}$ & $\begin{array}{r}47.40 \\
14.88 \\
0.14 \\
8.60 \\
8.34 \\
0.28 \\
5.68 \\
1.41 \\
0.16 \\
0.02\end{array}$ & $\begin{array}{r}56.00 \\
12.95 \\
0.21 \\
5.24 \\
7.20 \\
0.27 \\
2.50 \\
0.42 \\
0.68 \\
-\end{array}$ \\
\hline Total & 86.46 & 83.64 & 88.43 & 82.28 & 81.83 & 93.43 & 91.91 & 92.01 & 90.78 & 80.34 & 86.91 & 85.47 \\
\hline $\begin{array}{l}\text { XFe } \\
\text { Allv } \\
\text { AlVI }\end{array}$ & $\begin{array}{r}20.400 \\
0.378 \\
0.314\end{array}$ & $\begin{array}{r}16.800 \\
0.000 \\
0.341\end{array}$ & $\begin{array}{r}16.900 \\
0.510 \\
0.416\end{array}$ & $\begin{array}{r}18.400 \\
0.460 \\
0.458\end{array}$ & $\begin{array}{r}31.800 \\
0.748 \\
0.000\end{array}$ & $\begin{array}{r}42.000 \\
0.000 \\
1.003\end{array}$ & $\begin{array}{r}53.900 \\
0.000 \\
0.776\end{array}$ & $\begin{array}{l}55.90 \\
0.000 \\
0.904\end{array}$ & $\begin{array}{l}55.20 \\
0.000 \\
0.925\end{array}$ & $\begin{array}{l}41.70 \\
0.285 \\
2.170\end{array}$ & $\begin{array}{l}36.60 \\
0.990 \\
1.604\end{array}$ & $\begin{array}{l}29.00 \\
0.004 \\
2.176\end{array}$ \\
\hline $\begin{array}{l}\text { Type } \\
\text { Occurrence }\end{array}$ & $\begin{array}{l}\text { Saponite } \\
\text { Olivine }\end{array}$ & $\begin{array}{l}\text { Saponite } \\
\text { Olivine }\end{array}$ & $\begin{array}{l}\text { Saponite } \\
\text { Groundmass }\end{array}$ & $\begin{array}{l}\text { Saponite } \\
\text { Olivine }\end{array}$ & $\begin{array}{l}\text { Saponite } \\
\text { Olivine }\end{array}$ & $\begin{array}{l}\text { Celadonite } \\
\text { Olivine }\end{array}$ & $\begin{array}{l}\text { Celadonite } \\
\text { Cracks in OPX }\end{array}$ & $\begin{array}{l}\text { Celadonite } \\
\text { Vesicles }\end{array}$ & $\begin{array}{l}\text { Celadonite } \\
\text { Vesicles }\end{array}$ & $\begin{array}{l}\text { Illite } \\
\text { Glass inclusions } \\
\text { in CPX }\end{array}$ & $\begin{array}{l}\text { Illite } \\
\text { Groundmass }\end{array}$ & $\begin{array}{l}\text { Illite } \\
\text { Groundmass }\end{array}$ \\
\hline Rock type & Diabase & Diabase & Type II & Type I & Type I & Type 1 & Type II & Type III & Type IV & Type IV & Type II & Type III \\
\hline
\end{tabular}

Notes: The structural formulas was calculated on the basis of 32 oxygenes. The numbers in parentheses correspond to the sample numbers analyzed for major and trace element chemistry (Taylor et al., this volume). OPX = orthopyroxene and CPX = clinopyroxene.

459B. In Hussong, D. M., Uyeda, S., et al., Init. Repts. DSDP, 60: Washington (U.S. Govt. Printing Office), 735-742.

Hickey-Vargas, R. L., 1989. Boninites and tholeiites from DSDP Site 458, Mariana forearc. In Crawford, A. J. (Ed.), Boninites and Related Rocks: London (Unwin Hyman), 339-356.

Hussong, D. M., and Uyeda, S., 1982. Mariana arc and forearc background and objectives. In Hussong, D. M., and Uyeda, S., Init. Reports DSDP, 60: Washington (U.S. Govt. Printing Office), 251-254.

Kuroda, N., Shiraki, K., and Urano, H., 1978. Boninite as a possible calc-alkalic primary magma. Bull. Volcanol., 41:563-575.

Kushiro, I., 1960. Si-Al relations in clinopyroxenes from igneous rocks. Am. J. Sci., 258:548-554.

, 1969. The system forsterite-diopside-silica with and without water at high pressures. Am. J. Sci., Schairer Vol., 267A:269-274.

Leg 126 Shipboard Scientific Party, 1989a. Arc volcanism and rifting. Nature, 342:18-20.

,1989b. ODP Leg 126 drills the Izu-Bonin Arc. Geotimes, 34:36-38.

Le Bas, M. J., 1962. The role of aluminum in igneous clinopyroxenes with relation to their parentage. Am. J. Sci., 260:267-288.

Leterrier, J., Maury, R. C., Thonon, P., Girard, D., and Marchal, M., 1982. Clinopyroxene composition as a method of identification of the magmatic affinities of paleo-volcanic series. Earth Planet. Sci. Lett., 59:139-154.

McBirney, A. R., 1984. Igneous Petrology: San Francisco (Freeman, Cooper and Co.).

Meijer, A., Anthony, E., and Reagan, M., 1982. Petrology of volcanic rocks from the forearc sites. In Hussong, D. M., Uyeda, S., et al., Init. Repts. DSDP, 60: Washington (U.S. Govt. Printing Office), 709-729.

Mollard, J. P., Maury, R. C., Leterrier, J., and Bourgeois, J., 1983. Teneurs en chrome et titane des clinopyroxènes calciques des basaltes: application à l'identification des affinités magmatiques de roches paléovolcaniques. $C$. R. Acad. Sci. Ser. 2, 296:903-908.

Natland, J. H., 1982. Crystal morphologies and pyroxene compositions in boninites and tholeiitic basalts from Deep Sea Drilling Project Holes 458 and 459 $\mathrm{B}$ in the Marana fore-arc region. In Hussong, D. M., Uyeda, S., et al., Init. Repts. DSDP, 60: Washington (U.S. Govt. Printing Office), 681-707.
Nisbet, E. G., and Pearce, J. A., 1977. Clinopyroxene composition in mafic lavas from different tectonic settings. Contrib. Mineral. Petrol., 63:149-160.

Parron, C., and Amouric, M., 1990. Crystallochemical heterogeneity of glauconites and the related problem of glauconite-celadonite distinction. Geochemistry of the Earth's Surface and of Mineral Formation, 2nd Inter. Symp., Rome.

Poldervaart, A., and Hess, H. H., 1951. Pyroxenes in the crystallization of basaltic magma. J. Geol., 19:472-489.

Sakuyama, M., 1984. Magma mixing and magma plumbing systems in island arcs. Bull. Volcanol., 47:685-703.

Stevens, R. E., 1944. Composition of some chromites of the Western Hemisphere. Am. Min., 29:1-34.

Tagikami, Y., and Ozima, M., 1982. ${ }^{40} \mathrm{Ar}-{ }^{39} \mathrm{Ar}$ dating of rocks drilled at Sites 458 and 459 in the Mariana forearc region during Leg 60. In Hussong, D. M., Uyeda, S., et al., Init. Repts. DSDP, 60: Washington (U.S. Govt. Printing Office), 743-736.

Tatsumi, Y., and Ishizoka, K., 1982. Magnesian andesite and basalt from Shodo-Shima island, southwestern Japan, and their bearing on the genesis of calc-alkaline andesites. Lithos, 15:161-172.

Taylor, B., Fujioka, K., et al., 1990. Proc. ODP, Init. Repts., 126: College Station, TX (Ocean Drilling Program).

Thorette, J., 1987. Contribution à l'étude de l'hydrothermalisme océanique: example du district minéralisé de York-Harbour (ophiolite de Blow-Me-Down, Bay-Of-Island, Terre-Neuve) [Thèse]. Ecole des Mines de Paris, France.

Walker, D., Kirkpatrick, R. J., Longhi, J., and Hays, J. F., 1976. Crystallization history of lunar picritic basalt sample 12002: phase equilibria and coolingrate studies. Geol. Soc. Am. Abstr. Programs, 18:195.

Winkler, H.G.F., 1974. Petrogenesis of Metamorphic Rocks: New York (Springer-Verlag).

Wood, C.P., 1980. Boninite at a continental margin. Nature, 288:692-694.

Date of initial receipt: 10 January 1991

Date of acceptance: 12 September 1991

Ms 126B-147 
Table 8. Zeolite (heulandite) representative compositions, Hole 793B.

\begin{tabular}{|c|c|c|c|c|}
\hline $\begin{array}{l}\text { Core, section } \\
\text { Interval (cm) }\end{array}$ & $\begin{array}{c}104 \mathrm{R}-2(55) \\
69-75\end{array}$ & $\begin{array}{c}104 R-2(55) \\
69-75\end{array}$ & $\begin{array}{c}104 R-2(55) \\
69-75\end{array}$ & $\begin{array}{c}104 R-2(55) \\
69-75\end{array}$ \\
\hline $\mathrm{SiO}_{2}$ & 65.52 & 64.95 & 66.16 & 65.99 \\
\hline $\mathrm{Al}_{2} \mathrm{O}_{3}$ & 14.92 & 14.96 & 14.65 & 14.65 \\
\hline $\mathrm{FeO}$ & - & 0.05 & - & - \\
\hline $\begin{array}{l}\mathrm{MgO} \\
\mathrm{CaO}\end{array}$ & $\overline{3} .93$ & $\overline{4}_{4} .03$ & $\overline{3} .98$ & $\overline{3} .75$ \\
\hline $\mathrm{Na}_{2} \mathrm{O}$ & 2.07 & $\begin{array}{l}1.03 \\
1.90\end{array}$ & 2.68 & 3.16 \\
\hline $\mathrm{K}_{2} \mathrm{O}$ & 0.26 & 0.26 & 0.28 & 0.27 \\
\hline Total & 86.70 & 86.15 & 88.30 & 87.82 \\
\hline Site Z & 36.50 & 36.53 & 36.39 & 36.27 \\
\hline $\mathrm{Si} / \mathrm{Al}$ & 3.73 & 3.68 & 3.69 & 3.82 \\
\hline $\begin{array}{l}\text { Rock type } \\
\text { Occurrence }\end{array}$ & $\begin{array}{l}\text { Type III } \\
\text { Vesicles }\end{array}$ & $\begin{array}{l}\text { Type III } \\
\text { Vesicles }\end{array}$ & $\begin{array}{l}\text { Type III } \\
\text { Cracks }\end{array}$ & $\begin{array}{l}\text { Type III } \\
\text { Cracks }\end{array}$ \\
\hline
\end{tabular}

Notes: The structural formulas was calculated on the basis of 72 oxygenes. The numbers in parentheses correspond to the sample numbers analyzed for major and trace element chemistry (Taylor et al., this volume).

Table 9. Andesite plagioclase compositions, Hole 792B.

\begin{tabular}{|c|c|c|c|c|c|c|c|c|}
\hline $\begin{array}{c}\text { Core, section } \\
\text { Interval }(\mathrm{cm}) \text { or piece no. }\end{array}$ & $\begin{array}{c}71 R-1(100) \\
18-20\end{array}$ & $\begin{array}{c}71 \mathrm{R}-1(100) \\
18-20\end{array}$ & $\begin{array}{c}71 \mathrm{R}-1(100) \\
18-20\end{array}$ & $\begin{array}{l}\text { 76R-1 (108) } \\
\text { Piece } 4\end{array}$ & $\begin{array}{l}\text { 76R-1 (108) } \\
\text { Piece } 4\end{array}$ & $\begin{array}{l}\text { 76R-1 (108) } \\
\text { Piece } 4\end{array}$ & $\begin{array}{l}\text { 76R-1 (108) } \\
\text { Piece } 4\end{array}$ & $\begin{array}{l}\text { 76R-1 (108) } \\
\text { Piece } 4\end{array}$ \\
\hline $\begin{array}{l}\mathrm{SiO}_{2} \\
\mathrm{Al}_{2} \mathrm{O}_{3} \\
\mathrm{FeO} \\
\mathrm{CaO} \\
\mathrm{Na}_{2} \mathrm{O} \\
\mathrm{K}_{2} \mathrm{O}\end{array}$ & $\begin{array}{r}47.22 \\
32.87 \\
0.87 \\
16.13 \\
1.88 \\
0.01\end{array}$ & $\begin{array}{r}47.07 \\
33.56 \\
0.61 \\
16.15 \\
1.82 \\
-\end{array}$ & $\begin{array}{r}50.15 \\
30.68 \\
0.52 \\
13.87 \\
2.97 \\
0.04\end{array}$ & $\begin{array}{r}47.92 \\
32.40 \\
0.41 \\
15.73 \\
2.07 \\
-\end{array}$ & $\begin{array}{r}49.69 \\
31.41 \\
0.51 \\
14.22 \\
2.86 \\
-\end{array}$ & $\begin{array}{r}48.90 \\
31.74 \\
0.62 \\
14.93 \\
2.57 \\
0.01\end{array}$ & $\begin{array}{r}47.87 \\
32.53 \\
0.63 \\
15.56 \\
2.07 \\
-\end{array}$ & $\begin{array}{r}51.64 \\
30.29 \\
0.53 \\
13.28 \\
3.51 \\
0.05\end{array}$ \\
\hline Total & 98.96 & 99.19 & 98.23 & 98.53 & 98.76 & 98.76 & 98.46 & 99.10 \\
\hline$\%$ An & 82.6 & 83.1 & 71.9 & 80.8 & 73.3 & 76.2 & 80.6 & 68.7 \\
\hline Unit & $\begin{array}{l}\text { Fresh } \\
\text { phenocryst } \\
\text { core } \\
\text { Unit 1 }\end{array}$ & $\begin{array}{l}\text { Fresh } \\
\text { phenocryst } \\
\text { intermediate } \\
\text { Unit 1 }\end{array}$ & $\begin{array}{l}\text { Fresh } \\
\text { phenocryst } \\
\text { rim } \\
\text { Unit1 }\end{array}$ & $\begin{array}{l}\text { Fresh } \\
\text { phenocryst } \\
\text { core } \\
\text { Unit } 2\end{array}$ & $\begin{array}{l}\text { Fresh } \\
\text { phenocryst } \\
\text { intermediate } \\
\text { Unit 2 }\end{array}$ & $\begin{array}{l}\text { Fresh } \\
\text { phenocryst } \\
\text { intermediate } \\
\text { Unit } 2\end{array}$ & $\begin{array}{l}\text { Fresh } \\
\text { phenocryst } \\
\text { intermediate } \\
\text { Unit } 2\end{array}$ & $\begin{array}{l}\text { Fresh } \\
\text { phenocryst } \\
\text { rim } \\
\text { Unit } 2\end{array}$ \\
\hline
\end{tabular}

Notes: The structural formulas was calculated on the basis of eight oxygenes. The numbers in parentheses correspond to the sample numbers analyzed for major and trace element chemistry (Taylor et al., this volume). OPX = orthopyroxene and CPX = clinopyroxene.

Table 9 (continued).

\begin{tabular}{|c|c|c|c|c|}
\hline $\begin{array}{c}\text { Core, section } \\
\text { Interval }(\mathrm{cm}) \text { or piece no. }\end{array}$ & $\begin{array}{c}75 R-2(114) \\
69-73\end{array}$ & $\begin{array}{c}75 R-1(112) \\
18-22\end{array}$ & $\begin{array}{c}71 \mathrm{R}-1(100) \\
18-20\end{array}$ & $\begin{array}{c}73 \mathrm{R}-1(104) \\
18-21\end{array}$ \\
\hline $\begin{array}{l}\mathrm{SiO}_{2} \\
\mathrm{Al}_{2} \mathrm{O}_{3} \\
\mathrm{FeO} \\
\mathrm{CaO} \\
\mathrm{Na}_{2} \mathrm{O} \\
\mathrm{K}_{2} \mathrm{O}\end{array}$ & $\begin{array}{r}51.96 \\
30.04 \\
0.58 \\
13.52 \\
3.79 \\
0.05\end{array}$ & $\begin{array}{r}47.12 \\
33.56 \\
0.70 \\
17.69 \\
1.36 \\
-\end{array}$ & $\begin{array}{r}48.58 \\
32.22 \\
0.96 \\
16.17 \\
2.02 \\
0.03\end{array}$ & $\begin{array}{r}50.31 \\
32.23 \\
0.59 \\
14.69 \\
3.17 \\
0.01\end{array}$ \\
\hline Total & 99.92 & 100.43 & 99.97 & 99.98 \\
\hline$\%$ An & 66.2 & 87.8 & 81.5 & 71.9 \\
\hline State & $\begin{array}{l}\text { Fresh } \\
\text { microphenocryst } \\
\text { around Opx } \\
\text { Unit } 3\end{array}$ & $\begin{array}{l}\text { Fresh } \\
\text { microphenocryst } \\
\text { included in Cpx } \\
\text { Unit } 1\end{array}$ & $\begin{array}{l}\text { Fresh } \\
\text { microlite }\end{array}$ & $\begin{array}{l}\text { Fresh } \\
\text { microlite }\end{array}$ \\
\hline
\end{tabular}


Table 10. Andesite-clinopyroxene compositions, Hole 792E.

\begin{tabular}{|c|c|c|c|c|c|c|c|c|c|c|c|}
\hline $\begin{array}{l}\text { Core, section } \\
\text { Interval }(\mathrm{cm}) \text { or piece no. }\end{array}$ & $\begin{array}{c}7 \mid \begin{array}{c}7 R-1 \\
\mid 8-21\end{array} \\
100)\end{array}$ & $\begin{array}{c}7 \mid \mathrm{R}-1(100) \\
\mid 8-21\end{array}$ & $\begin{array}{c}73 \mathrm{R}-1(104) \\
18-21\end{array}$ & $\begin{array}{c}73 R-1(104) \\
18-21\end{array}$ & $\begin{array}{l}\text { 76R-1 (108) } \\
\text { Piece 4 }\end{array}$ & $\begin{array}{c}\text { 76R-1 (108) } \\
\text { Piece 4 }\end{array}$ & $\begin{array}{c}75 R-1(112) \\
18-22\end{array}$ & $\underset{18-22}{75 R-1(112)}$ & $\begin{array}{l}75 R-1(112) \\
18-22\end{array}$ & $\begin{array}{c}75 R-2(114) \\
\text { Piece } 4\end{array}$ & $\begin{array}{c}\text { 75R-2 (114) } \\
\text { Piece } 4\end{array}$ \\
\hline $\begin{array}{l}\mathrm{SiO}_{2} \\
\mathrm{Al}_{2} \mathrm{O}_{3} \\
\mathrm{TiO}_{2} \\
\mathrm{FeO} \\
\mathrm{MgO} \\
\mathrm{CaO} \\
\mathrm{MnO} \\
\mathrm{Cr}_{2} \mathrm{O}_{3} \\
\mathrm{Na}_{2} \mathrm{O}\end{array}$ & $\begin{array}{r}52.44 \\
1.77 \\
0.32 \\
10.66 \\
13.98 \\
20.12 \\
0.37 \\
0.15 \\
0.25\end{array}$ & $\begin{array}{r}52.66 \\
2.00 \\
0.33 \\
9.66 \\
14.34 \\
20.70 \\
0.39 \\
0.07 \\
0.36\end{array}$ & $\begin{array}{r}51.09 \\
2.27 \\
0.47 \\
10.70 \\
13.52 \\
20.63 \\
0.41 \\
0.30\end{array}$ & $\begin{array}{r}52.72 \\
1.48 \\
0.39 \\
10.25 \\
14.35 \\
20.72 \\
0.44 \\
-0.15\end{array}$ & $\begin{array}{r}52.35 \\
1.63 \\
0.36 \\
11.05 \\
14.33 \\
19.44 \\
0.61 \\
0.22 \\
0.27\end{array}$ & $\begin{array}{r}51.23 \\
4.34 \\
0.32 \\
6.89 \\
17.15 \\
19.41 \\
0.08 \\
0.26 \\
0.12\end{array}$ & $\begin{array}{r}52.70 \\
1.71 \\
0.31 \\
10.62 \\
13.80 \\
20.57 \\
0.36 \\
-\quad 0.27\end{array}$ & $\begin{array}{r}52.52 \\
1.62 \\
0.35 \\
10.62 \\
13.61 \\
20.72 \\
0.27 \\
-0.21\end{array}$ & $\begin{array}{r}52.89 \\
1.83 \\
0.28 \\
10.57 \\
13.66 \\
20.58 \\
0.43 \\
\overline{0.21}\end{array}$ & $\begin{array}{r}52.02 \\
1.88 \\
0.34 \\
10.95 \\
13.88 \\
20.41 \\
0.39 \\
0.02 \\
0.24\end{array}$ & $\begin{array}{r}51.99 \\
1.96 \\
0.30 \\
10.18 \\
13.99 \\
20.22 \\
0.43 \\
0.03 \\
0.21\end{array}$ \\
\hline Total & 100.07 & 100.50 & 99.38 & 100.50 & 100.26 & 99.80 & 100.34 & 99.92 & 100.43 & 100.14 & 99.31 \\
\hline $\begin{array}{l}\text { \%En } \\
\text { \%Fs } \\
\text { \% Wo }\end{array}$ & $\begin{array}{l}40.4 \\
17.9 \\
41.8\end{array}$ & $\begin{array}{l}41.1 \\
16.2 \\
42.7\end{array}$ & $\begin{array}{l}39.1 \\
18.0 \\
42.9\end{array}$ & $\begin{array}{l}40.7 \\
17.0 \\
42.3\end{array}$ & $\begin{array}{l}41.1 \\
18.8 \\
40.1\end{array}$ & $\begin{array}{l}49.0 \\
11.2 \\
39.8\end{array}$ & $\begin{array}{l}39.7 \\
17.7 \\
42.8\end{array}$ & $\begin{array}{l}39.3 \\
17.7 \\
43.0\end{array}$ & $\begin{array}{l}39.5 \\
17.8 \\
42.7\end{array}$ & $\begin{array}{l}39.7 \\
18.2 \\
42.0\end{array}$ & $\begin{array}{l}40.6 \\
17.3 \\
42.2\end{array}$ \\
\hline $\begin{array}{l}\text { Allv } \\
\text { AlVI } \\
\text { XFe }\end{array}$ & $\begin{array}{l}0.040 \\
0.038 \\
0.300\end{array}$ & $\begin{array}{l}0.047 \\
0.041 \\
0.274\end{array}$ & $\begin{array}{l}0.069 \\
0.032 \\
0.307\end{array}$ & $\begin{array}{l}0.039 \\
0.026 \\
0.286\end{array}$ & $\begin{array}{l}0.044 \\
0.028 \\
0.302\end{array}$ & $\begin{array}{l}0.117 \\
0.071 \\
0.184\end{array}$ & $\begin{array}{l}0.035 \\
0.040 \\
0.302\end{array}$ & $\begin{array}{l}0.034 \\
0.038 \\
0.305\end{array}$ & $\begin{array}{l}0.032 \\
0.048 \\
0.303\end{array}$ & $\begin{array}{l}0.052 \\
0.031 \\
0.307\end{array}$ & $\begin{array}{l}0.045 \\
0.042 \\
0.290\end{array}$ \\
\hline State & $\begin{array}{l}\text { Fresh } \\
\text { phenocryst } \\
\text { core }\end{array}$ & $\begin{array}{l}\text { Fresh } \\
\text { phenocryst } \\
\text { rim }\end{array}$ & $\begin{array}{l}\text { Fresh } \\
\text { phenocryst } \\
\text { core }\end{array}$ & $\begin{array}{l}\text { Fresh } \\
\text { phenocryst } \\
\text { rim }\end{array}$ & $\begin{array}{l}\text { Fresh } \\
\text { phenocryst } \\
\text { core }\end{array}$ & $\begin{array}{l}\text { Fresh } \\
\text { microphenocryst } \\
\text { around Opx }\end{array}$ & $\begin{array}{l}\text { Fresh } \\
\text { phenocryst } \\
\text { rim }\end{array}$ & $\begin{array}{l}\text { Fresh } \\
\text { phenocryst } \\
\text { rim }\end{array}$ & $\begin{array}{l}\text { Fresh } \\
\text { microphenocrys } \\
\text { included in } \\
\text { plagioclase }\end{array}$ & $\begin{array}{l}\text { Fresh } \\
\text { phenocryst } \\
\text { rim }\end{array}$ & $\begin{array}{l}\text { Fresh } \\
\text { phenocryst } \\
\text { core }\end{array}$ \\
\hline $\begin{array}{l}\text { Unit } \\
\text { Rock type }\end{array}$ & $\begin{array}{l}\text { Unit I } \\
\text { Andesite }\end{array}$ & $\begin{array}{l}\text { Unit } 1 \\
\text { Andesite }\end{array}$ & $\begin{array}{l}\text { Unit } 1 \\
\text { Andesite }\end{array}$ & $\begin{array}{l}\text { Unit 1 } \\
\text { Andesite }\end{array}$ & $\begin{array}{l}\text { Unit } 2 \\
\text { Andesite }\end{array}$ & $\begin{array}{l}\text { Unit } 2 \\
\text { Andesite }\end{array}$ & $\begin{array}{l}\text { Unit VI } \\
\text { Dacite }\end{array}$ & $\begin{array}{l}\text { Unit } 1 \\
\text { Dacite }\end{array}$ & $\begin{array}{l}\text { Unit I } \\
\text { Dacite }\end{array}$ & $\begin{array}{l}\text { Unit } 3 \\
\text { Dacite }\end{array}$ & $\begin{array}{l}\text { Unit } 3 \\
\text { Dacite }\end{array}$ \\
\hline
\end{tabular}

Notes: The structural formulas was calculated on the basis of six oxygenes. The numbers in parentheses correspond to the sample numbers analyzed for major and trace element chemistry (Taylor et al., this volume). OPX = orthopyroxene and Plag = plagioclase.

Table 11. Basement anesite Fe-Ti oxides representative compositions, Hole 792E.

\begin{tabular}{|c|c|c|c|c|c|c|c|c|c|}
\hline $\begin{array}{l}\text { Core, section } \\
\text { Interval }(\mathrm{cm})\end{array}$ & $\begin{array}{c}71 \mathrm{R}-1(100) \\
18-21\end{array}$ & $\begin{array}{l}71 R-1(100) \\
18-21\end{array}$ & $\begin{array}{l}71 \mathrm{R}-1(100) \\
18-21\end{array}$ & $\begin{array}{c}73 R-1(104) \\
18-21\end{array}$ & $\begin{array}{c}73 R-1(104) \\
18-21\end{array}$ & $\begin{array}{l}73 R-1(104) \\
18-21\end{array}$ & $\begin{array}{l}75 \mathrm{R}-2(114) \\
69-73\end{array}$ & $\begin{array}{c}75 R-2(114) \\
69-73\end{array}$ & $\begin{array}{c}75 R-2(114) \\
69-73\end{array}$ \\
\hline $\begin{array}{l}\mathrm{TiO}_{2} \\
\mathrm{Al}_{2} \mathrm{O}_{3} \\
\mathrm{Cr}_{2} \mathrm{O}_{3} \\
\mathrm{FeO}^{*} \\
\mathrm{MnO} \\
\mathrm{MgO}\end{array}$ & $\begin{array}{r}8.17 \\
2.83 \\
78.11 \\
0.19 \\
1.57\end{array}$ & $\begin{array}{r}9.15 \\
2.42 \\
0.09 \\
77.66 \\
0.56 \\
1.00\end{array}$ & $\begin{array}{r}10.29 \\
2.45 \\
0.01 \\
78.22 \\
0.30 \\
1.28\end{array}$ & $\begin{array}{r}8.71 \\
2.71 \\
75.49 \\
0.41 \\
1.96\end{array}$ & $\begin{array}{r}9.52 \\
2.32 \\
0.07 \\
77.89 \\
0.38 \\
1.90\end{array}$ & $\begin{array}{r}9.35 \\
2.45 \\
0.09 \\
80.91 \\
0.39 \\
1.58\end{array}$ & $\begin{array}{r}9.08 \\
2.31 \\
78.60 \\
0.47 \\
1.75\end{array}$ & $\begin{array}{r}9.97 \\
2.45 \\
0.14 \\
79.25 \\
0.31 \\
1.65\end{array}$ & $\begin{array}{r}9.73 \\
2.21 \\
0.05 \\
80.88 \\
0.51 \\
1.46\end{array}$ \\
\hline Total & 90.86 & 91.76 & 92.55 & 89.27 & 92.07 & 94.77 & 92.20 & 93.76 & 94.84 \\
\hline $\begin{array}{l}\mathrm{Fe}_{2} \mathrm{O}_{3} \\
\mathrm{FeO}\end{array}$ & $\begin{array}{l}47.73 \\
36.10\end{array}$ & $\begin{array}{l}46.96 \\
35.41\end{array}$ & $\begin{array}{l}46.96 \\
35.41\end{array}$ & $\begin{array}{l}45.80 \\
34.28\end{array}$ & $\begin{array}{l}46.58 \\
35.98\end{array}$ & $\begin{array}{l}48.56 \\
37.22\end{array}$ & $\begin{array}{l}47.56 \\
35.80\end{array}$ & $\begin{array}{l}46.51 \\
37.40\end{array}$ & $\begin{array}{l}48.10 \\
37.60\end{array}$ \\
\hline $\begin{array}{l}\text { \% Magnetite } \\
\% \text { Hercynite } \\
\% \text { Ulvöspinel }\end{array}$ & $\begin{array}{r}91.5 \\
8.5 \\
25.5\end{array}$ & $\begin{array}{r}92.5 \\
7.4 \\
28.0\end{array}$ & $\begin{array}{r}92.1 \\
7.9 \\
30.4\end{array}$ & $\begin{array}{r}91.5 \\
8.5 \\
27.5\end{array}$ & $\begin{array}{r}92.6 \\
7.2 \\
29.0\end{array}$ & $\begin{array}{r}92.5 \\
7.3 \\
27.8\end{array}$ & $\begin{array}{r}92.9 \\
7.1 \\
27.6\end{array}$ & $\begin{array}{r}92.1 \\
7.6 \\
30.0\end{array}$ & $\begin{array}{r}93.2 \\
6.7 \\
28.8\end{array}$ \\
\hline $\begin{array}{l}\text { Occurrence } \\
\text { Rock type }\end{array}$ & $\begin{array}{l}\text { Inclusion in Cpx } \\
\text { Unit 1 }\end{array}$ & $\begin{array}{l}\text { Inclusion in Cpx } \\
\text { Unit } 1\end{array}$ & $\begin{array}{l}\text { Inclusion in Opx } \\
\text { Unit I }\end{array}$ & $\begin{array}{l}\text { Inclusion in Cpx } \\
\text { Unit I }\end{array}$ & $\begin{array}{l}\text { Groundmass (core) } \\
\text { Unit } 1\end{array}$ & $\begin{array}{l}\text { Groundmass (rim) } \\
\text { Unit I }\end{array}$ & $\begin{array}{l}\text { Inclusion in Cpx } \\
\text { Unit } 3\end{array}$ & $\begin{array}{l}\text { Inclusion in Opx } \\
\text { Unit } 3\end{array}$ & $\begin{array}{l}\text { Groundmass } \\
\text { Unit } 3\end{array}$ \\
\hline
\end{tabular}

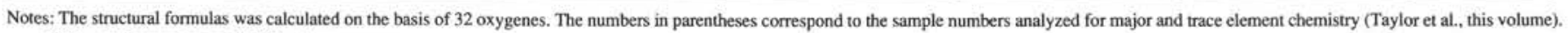
OPX $=$ orthopyroxene and $\mathrm{CPX}=$ clinopyroxene. 